\title{
The Northeast Atlantic Mackerel Crisis
}

\author{
Hougaard, Jens Leth; Jensen, Frank; Smilgins, Aleksandrs
}

Document Version

Accepted author manuscript

Published in:

Strategic Behavior and the Environment

DOI:

$10.1561 / 102.00000092$

Publication date:

2020

License

Unspecified

Citation for published version (APA):

Hougaard, J. L., Jensen, F., \& Smilgins, A. (2020). The Northeast Atlantic Mackerel Crisis. Strategic Behavior and the Environment, 8(2), 169-218. https://doi.org/10.1561/102.00000092

Link to publication in CBS Research Portal

\section{General rights}

Copyright and moral rights for the publications made accessible in the public portal are retained by the authors and/or other copyright owners and it is a condition of accessing publications that users recognise and abide by the legal requirements associated with these rights.

Take down policy

If you believe that this document breaches copyright please contact us (research.lib@cbs.dk) providing details, and we will remove access to the work immediately and investigate your claim. 


\section{The Northeast Atlantic Mackerel Crisis Jens Leth Hougaard, Frank Jensen, and Aleksandrs Smilgins}

Journal article (Accepted manuscript*)

\section{Please cite this article as:}

Jens Leth Hougaard, Frank Jensen and Aleksandrs Smilgins (2020), "The Northeast Atlantic Mackerel Crisis", Strategic Behavior and the Environment: Vol. 8: No. 2, pp 169-218. http://dx.doi.org/10.1561/102.00000092

\section{DOI: 10.1561/102.00000092}

Uploaded to CBS Research Portal in agreement with now publishers

* This version of the article has been accepted for publication and undergone full peer review but has not been through the copyediting, typesetting, pagination and proofreading process, which may lead to differences between this version and the publisher's final version AKA Version of Record.

Uploaded to CBS Research Portal: May 2020 


\title{
The Northeast Atlantic Mackerel Crisis
}

\author{
Jens Leth Hougaarda, Frank Jensen ac and Aleksandrs Smilgins ${ }^{\mathrm{b}}$ \\ a University of Copenhagen, Department of Food and Resource Economics, \\ Rolighedsvej 25, 1958 Frederiksberg C, Denmark. \\ b Copenhagen Business School, Department of Economics, Porcelænshaven 16a, \\ 2000 Frederiksberg, Denmark.
}

c Corresponding author, e-mail: fje@ifro.ku.dk; phone: 004535336898.

Keywords: The Mackerel Crisis; Game Theory; Internally Stable Coalitions.

JEL codes: Q22; C72; C61.

\begin{abstract}
From 2010 and onwards, a crisis have occurred over the distribution of a yearly total allowable catch (TAC) for the mackerel fishery in the Northeast Atlantic Sea. The European Union (the EU), Norway (NO), Iceland (IC) and the Faroe Islands (the FI) are players in this "mackerel crisis". In the present study, we use game theory in an attempt to rationalize the actual behaviour of these players during the mackerel crisis. We identify the profit of each possible coalition structure (the coalitional values) by using a fisheries economic model, and quantify the coalitional values empirically by statistical estimation of the relevant functional relationships. Based on the statistical estimations, we define a benchmark scenario and conduct a number of sensitivity analyses. To try to rationalize the outcome during the mackerel crisis, we require that a relevant coalition must be internally stable in the sense that no structure has an incentive to split-up. By using the notion of internal stability, we are partly able to rationalize the actual coalition formation during the mackerel crisis.
\end{abstract}




\section{Introduction}

\subsection{Setting the scene}

Between 1999 and 2009, the European Union (the EU), Norway (NO) and the Faroe Islands (the FI) had an agreement on the size and distribution of a total allowable catch (TAC) for the mackerel fishery in the Northeast Atlantic Sea. A TAC is defined as a yearly total quota announced for a group of actors ex-ante (see Holden, 1996). However, in 2010, Iceland (IC) was also officially recognized as an actor in the mackerel fishery by the EU, NO and the FI, partly because of a dramatic increase in harvest (The Icelandic Ministry of Fisheries, 2009). Some biologists claimed that the entry by IC into the fishery was due to changed migration patterns of the mackerel fish stock (see ICES, 2010). Consequently, IC entered into negotiations with the EU, NO and the FI to establish a common TAC for the Northeast Atlantic mackerel fish stock, but no agreement was reached among the four actors. Instead, the EU and NO signed a bilateral agreement in 2010 regarding the relative allocation of a common TAC for a ten-year period, while IC and the FI acted on their own and increased the harvest considerably (The Norwegian Ministry of Fisheries, 2010a). Specifically, IC increased the harvest by $23 \%$, and the FI increased the harvest by 15\% (see ICES, 2010). In total, the harvest was 40\% greater than the biological recommendations in 2010 (see ICES, 2010); therefore, the EU and NO banned landings of vessels from IC and the FI in their harbours (The Norwegian Ministry of Fisheries, 2010b). Although several bargaining attempts were undertaken between 2011 and 2014, they all failed. However, in 2014 the EU, NO and the FI entered an agreement about the relative allocation of a yearly TAC for the period between 2014 and 2018 while IC still acted independently (The Norwegian Government, 2014). According to this agreement, the TAC shares of the EU and NO were decreased while those of the FI were increased. To conclude, four main facts characterize the mackerel crisis: 1 . The EU, NO, IC and the FI did not enter an agreement involving all four actors; 2 . IC and the FI acted independently until 2014 by increasing their harvest; 3. The EU and NO had a bilateral agreement regarding a yearly TAC for the period between 2010 and 2014; 4. The EU, NO and the FI entered an agreement in 2014 while IC still acted independently.

\subsection{The mackerel crisis as a game}


In the present study, we analyse the economics behind the observed strategic behaviour of the players during the Northeast Atlantic mackerel crisis by using game theory. The mackerel crisis is a good example of the type of problems that can occur when it is impossible to allocate values among involved players such that a socially optimal situation is obtained. We quantify the profit obtained by each possible coalition structure (the coalitional values) for the fishery and identify internally stable coalition structures which arise if a coalition has no incentive to split-up.

Our analysis of the mackerel crisis involves four players: the EU, NO, IC and the FI. No cost information exists for the FI; however, the fleet structure for the mackerel fishery in the Northeast Atlantic Sea is similar in IC and the FI (see Jensen et al., 2018 and ICES, 2017). Therefore, we approximate the costs of the FI by using the cost information for IC and adjust these with the relative aggregated harvest share of the FI in relation to IC from ICES (2017). Only two alternatives exist: 1 . Include the FI as a part of IC; 2 . Exclude the FI from the analysis. Both alternatives imply a three-player game, but the outcome of a game may depend critically on the number of players (see e.g., Friedman, 1979). Therefore, we include the FI as a separate player despite lack of cost information.

\subsection{The purpose of the paper}

The study of the mackerel crisis presented herein is based on a theoretical model for fisheries in which the strategic interaction between the players is explicitly included. From the description in section 1.1, it is natural to choose harvest as a strategic variable. A resource restriction is included when a grand coalition involving all four players is formed but this restriction is disregarded for all other coalition structures (including when all players standalone). Furthermore, a negatively sloped demand function is taken into account implying that strategic interaction occurs through price. Based on the theoretical model, we identify the coalitional values during the mackerel crisis. All theoretical relationships are estimated, including cost functions for each possible coalition structure, and the cost function is assumed to depend in a non-linear way on both the fish stock size and the harvest.

In this paper, we consider two main research questions:

1. Can we rationalize the outcome during the mackerel crisis by using our model? 
2. Which economic factors may potentially influence the outcome during the mackerel crisis?

Regarding the first research question we construct a benchmark scenario and show that the only internally stable coalition structure occur where IC and the FI form a coalition while the EU and NO stand-alone. Thus, in the benchmark case we are able to rationalize why a grand coalition has not been formed during the mackerel crisis. However, we are unable to rationalize: 1. Why the EU and NO had a bilateral agreement for the period between 2010 and 2014; 2. Why IC and the FI acted independently until 2014; 3. Why the FI entered an agreement with the EU and NO in 2014. Nevertheless, these results may be due to statistical and data uncertainty and therefore we have conducted a number of sensitivity analyses. For some of the variations in the cost parameters, we obtain that the actual coalition formation during the mackerel crisis may be internally stable. Specifically, we reach two main conclusions: 1 . If the cost parameter of a two-player coalition involving the EU and NO or the cost parameter of all coalitions involving NO is decreased, an internally stable coalition arise where the EU and NO cooperate while IC and the FI stand-alone; 2. If the cost of a three-player coalition involving the EU, NO and the FI or the cost parameter of all coalitions involving NO is decreased, an internally stable coalition occur where the EU, NO and the FI cooperate while IC is standing-alone.

The results of the sensitivity analyses is also used to answer the second research question. By using fisheries economic arguments, we are able to explain how variations in the parameter values affect the coalitional values. Furthermore, we show that varying the parameters in the demand function does not affect which coalition structures that is internally stable. The explanation for this result is that the parameters in the demand function affects the value of all coalition structures in a similar way. We obtain an identical result for the parameters in the growth function but a resource restriction (growth function) is only included when the players form a grand coalition. Thus, even with large variations in the parameters in the growth function (the intrinsic growth rate and carrying capacity) the grand coalition does not become internally stable. However, the parameters in the cost functions may potentially affect which coalitions that is internally stable because a separate cost function is estimated for each coalition. Of particular importance for which coalitions that are internally stable is the cost 
parameters for structures involving NO because this player has very high total costs in the benchmark case.

Finally, Cheung et al. (2012) and Miller et al. (2013) argue that the mackerel fish stock changed migration patterns due to climate change. In our game theory analysis, we focus on the economic impact of the changed migration patterns, an impact that is captured by the coalitional values. Therefore, we implicitly account for climate change issues in our study.

\subsection{Existing literature}

With this paper, we contribute to two strands of fisheries economic literature. First, we address the existent economic literature on the mackerel crisis (see Ellefsen, 2013, Hannesson, 2012 and Jensen et al., 2015). Hannesson (2012) constructed a non-cooperative game theoretical model for the mackerel fishery with a major player (the EU and NO) and a minor player (IC and the FI). Hannesson (2012) focus on the change in the migration patterns of the mackerel fish stock and, thereby, the entry of IC into the fishery. Ellefsen (2013) also focus on the entry of IC into the fishery by comparing a three-player cooperative game (including the EU, NO and the FI) with a four-player game (adding IC to the group of players). In both papers, the possibility of cooperation involving all four players decrease with entry of IC. Jensen et al. (2015) consider the actual behaviour of the EU, NO, IC and the FI during the mackerel crisis and show that standing-alone by all players is a Nash equilibrium in a noncooperative game. With this paper, we contribute to the existent literature on the mackerel crisis by identifying economic factors that are potentially important for the coalition formation by conducting a number of sensitivity analyses.

Second, our paper is related to the fisheries economic literature applying the concept of internally stable coalitions (see e.g. Pintassilgo, 2003, Pintassilgo et al., 2008, Pintassilgo and Lindroos, 2009, Gronbæk and Lindroos, 2007 and Pham Do and Folmer, 2006). Of particular importance for our paper is Pintassilgo et al. (2008) and Pintassilgo and Lindroos (2009) who argue that it is unlikely to form coalitions that are internally stable for fisheries even with a low number of players. However, the analysis in Pintassilgo et al. (2008) and Pintassilgo and Lindroos (2009) are mainly theoretical while we use the concept of internally stable coalition 
structures to try to rationalize the behaviour for an actual empirical case (the mackerel crisis). In this way, we contribute to the existing literature on internally stable coalitions for fisheries.

\subsection{Content}

The remaining parts of the paper is organized as follows: A theoretical model for identifying the coalitional values is presented in section 2; the parameterization of relevant functions for the Northeast Atlantic mackerel fishery is discussed in section 3; and sections 4 and 5 present the results of the empirical analysis and our conclusions, respectively.

\section{A theoretical model}

In this section, we present a theoretical model, which is used to estimate the coalitional values during the mackerel crisis. In presenting the model, we distinguished between a grand coalition and other coalition structures (including when all players stand-alone). However, first we provide a formal description of the game.

\subsection{Description of the game}

We let $N=\{E U, N O, I C, F I\}$ denote the set of players. Since we want to study coalition formation, we defined $S \subseteq N$ as any possible coalition structure involving the players (including the grand coalition and when all players stand-alone), and in total, we consider 15 possible coalitions. Furthermore, we let $h$ be the aggregated harvest by all coalitions, while $h s$ represents the harvest by any coalition structure. If the players form a grand coalition, the aggregated harvest is identical to the harvest of the coalition. In the model, we want to incorporate strategic interaction between the players throughout the price. This is accomplished in an easy way by assuming that the harvest of mackerel by different players are perfect substitutes. Therefore, the demand function depends on the aggregated harvest by all players and we denote this function by $P(h)$, where $P$ is the market price. It is assumed that $\frac{\partial P}{\partial h}<0$, indicating that the demand function is negatively sloped. We let $C_{S}\left(h_{S}, x\right)$ be a cost function of any possible coalition structure, where $x$ is the stock size of mackerel. We assume that: $1 . \frac{\partial C_{S}}{\partial h_{S}}>0$ indicating that the marginal harvesting cost is positive for all possible 
coalition structures; $2 . \frac{\partial C_{S}}{\partial x}<0$ indicating that an increase in the stock size will decrease the costs because harvesting become easier (and less costly). These assumptions about the cost function capture what has been labelled a search fishery but mackerel can be argued to be a schooling fishery from which it follows that $\frac{\partial C_{S}}{\partial x}=0$ (see Neher, 1990). However, even in the purest schooling fisheries, a small stock effect in the cost function probably exists, so it is seems to be reasonable to assume that $\frac{\partial C_{S}}{\partial x}<0$ when modelling the mackerel crisis.

\subsection{The grand coalition}

The model for the grand coalition can be interpreted as a full social optimum. In a model for a social optimum, it is common in fisheries economics to include a resource restriction in the maximization problem (see e.g. Clark, 1990). In the most general case, where we allow for adjustments towards a steady-state equilibrium (a dynamic model), this restriction states that (see Conrad and Clark (1991) for a textbook presentation):

$$
\frac{d x}{d t}=G\left(x_{t}\right)-h_{t}
$$

where $t$ is an index for the time period, $\frac{d x}{d t}$ is the change in stock size between time periods, and $G\left(x_{t}\right)$ is a natural growth function. Equation (1) captures the notion that the change in stock size between time periods is equal to the natural growth minus the aggregated harvest. Regarding the growth function, we assume that $\frac{\partial G\left(x_{t}\right)}{\partial x_{t}}>0$ for $x_{t}<x_{M S Y}$, while $\frac{\partial G\left(x_{t}\right)}{\partial x_{t}}<0$ for $x_{t}>x_{M S Y}$, where $x_{M S Y}$ is the stock size corresponding to the maximum sustainable yield. Furthermore, we assume that $\frac{\partial^{2} G\left(x_{t}\right)}{\partial x_{t}^{2}}<0$.

In this paper, we assume that the social optimum, where a grand coalition is formed, is identical to a long-run steady-state equilibrium implying that $\frac{d x}{d t}=0$. Because we assume a 
steady-state equilibrium the time index on the harvest and stock size in equation (1) can be disregarded and we obtain that:

$$
G(x)-h=0
$$

Thus, in the long-run equilibrium the natural growth is equal to the aggregated harvest (see Clark, 1990). The steady-state equilibrium assumption can be discussed because actual fisheries are always on an adjustment path towards an equilibrium even in the long-run. Including such adjustment paths towards equilibrium in a fisheries model requires a dynamic game approach, and either an open-loop or closed-loop assumption must be imposed. In the theoretical literature on fisheries, it is common to consider dynamic games (see e.g., Hannesson, 2011 and Bailey et al., 2010); however, in an empirical analysis of an actual fishery, attention is normally restricted to a static steady-state equilibrium (see e.g., Kennedy, 2003, Armstrong and Flaaten, 1991, and Sumaila, 1997). We follow this tradition in the present study.

Regarding the objective function, two assumptions are imposed: 1 . The aggregated profit of the grand coalition, $\pi(h, x)$, is maximized with $h$ and $x$ as strategic variables; 2 . Discounting is disregarded because we are interested in a long-run steady-state equilibrium, although it is common to maximize the present value of current and future profits in fisheries economics (see Clark, 1990). With these assumptions, the objective function is:

$$
\underset{h, x}{\operatorname{Max}}[\pi]=\operatorname{Max}[P(h) h-C(h, x)]
$$

Equation (3) is maximized subject to equation (2). A Lagrange function can be constructed to solve this problem, but we adopt an alternative procedure which departs from the assumption that $\frac{\partial C}{\partial x}<0$. Now the derivatives of the growth function imply that the optimal harvest occur at the negatively sloped part of this function (see Jensen and Vestergaard, 2002). Therefore, equation (2) can be solved for $x$ and it is possible to restrict attention to the largest root of this equation. Thus, from equation (2) we get:

$$
x=M(h) .
$$


In equation (4), $M(h)$ can be interpreted as a biological response function, indicating how the steady-state equilibrium stock size responds to changes in harvest, and from the assumptions about the derivatives of the growth function we obtain that $\frac{\partial M}{\partial h}<0$.

Next, the biological response function in equation (4) can be substituted into equation (3), which yields:

$$
\operatorname{Max}[\pi]=\operatorname{Max}[P(h) h-C(h, M(h))]
$$

In equation (5), we have $h$ as the only strategic variable and we obtain the following firstorder conditions:

$$
\frac{\partial P}{\partial h} h+P(h)-\frac{\partial C}{\partial h}-\frac{\partial C}{\partial M} \frac{\partial M}{\partial h}=0
$$

In equation (6), $\frac{\partial C}{\partial M}$ is the marginal stock cost of the grand coalition, and $\frac{\partial M}{\partial h}$ is the marginal effect of the harvest on the steady-state equilibrium stock size. Thus, $\frac{\partial C}{\partial M} \frac{\partial M}{\partial h}$ is the marginal cost of harvesting through the effect on the stock size, and hence, equation (6) capture that the marginal revenue $\left(\frac{\partial P}{\partial h} h+P(h)\right)$ is equal to the marginal social harvesting costs $\left(\frac{\partial C}{\partial h}+\right.$ $\frac{\partial C}{\partial M} \frac{\partial M}{\partial h}$ ) for the grand coalition. Equation (6) can be solved to yield the optimal harvest of the grand coalition, $h^{*}$, from which the optimal stock size, $x^{*}$, can be found from equation (4). Finally, the coalitional value for the grand coalition, $\pi^{*}$, can be identified by inserting $h^{*}$ and $x^{*}$ into equation (2).

\subsection{Other coalition structures}

When quantifying the coalitional value for each possible coalition structure (apart from the grand coalition), we impose two assumptions: 1 . The coalitions play a non-cooperative Cournot-Nash game in quantities against each other (see Friedman, 1979). Thus, we identify a Cournot-Nash equilibrium in which each coalition takes the harvest of other coalitions as given when maximizing the profit, implying that $\frac{\partial h}{\partial h_{S}}=1 ; 2$. Each coalition acts myopically and 
maximises the short-run profit for each time period separately and treat the stock size as an exogenous parameter. Assumption 2 is common in conventional fisheries economics and corresponds to a traditional open-access assumption. The assumption imply that the resource restriction given by equation (2) is disregarded (see e.g. Clark, 1990). In the empirical analysis, we capture that the stock size is treated as an exogenous parameter by using the value of the variable for 2011 (see section 3.3.). An alternative is to include the resource restriction in equation (2) in the sense that this constraint is an additional condition that shall be taken into account when finding the optimal harvest. However, we choose to disregard the resource restriction because this is consistent with traditional fisheries economics (see e.g. Clark, 1990).

Given these two assumptions, each coalition maximizes the following profit expression:

$$
\begin{aligned}
& \operatorname{Max}\left(\pi_{S}\right)=\operatorname{Max}\left(P(h) h_{S}-C_{S}\left(h_{S}, x\right)\right) \\
& h_{S} \quad h_{S}
\end{aligned}
$$

In equation (7), the harvest is the only strategic variable and with Cournot-Nash expectations, the first-order condition is:

$$
\frac{\partial P}{\partial h} h_{S}+P(h)-\frac{\partial C_{S}}{\partial h_{S}}=0
$$

Equation (8) capture the notion that each coalition sets the marginal revenue $\left(\frac{\partial P}{\partial h} h_{S}+P(h)\right)$ equal to the marginal private $\operatorname{cost}\left(\frac{\partial C_{S}}{\partial h_{S}}\right)$. From equation (8), the nature of the strategic interaction that arises when the players decide on forming coalitions is clear since each coalition affects the other coalitions through a negatively sloped demand function (or through the marginal revenue).

Comparing equations (6) and (8) makes it clear that an externality arises when the players do not form a grand coalition. To see this note that equation (6) represents a social optimum and that the term $\frac{\partial C}{\partial M} \frac{\partial M}{\partial h}$ does not enter in equation (8). Thus, $\frac{\partial C}{\partial M} \frac{\partial M}{\partial h}$ expresses the marginal cost of the externality that arises because each coalition (apart from the grand coalition) does 
not consider the effect of their harvest on the stock size. For this reason, $\frac{\partial C}{\partial M} \frac{\partial M}{\partial h}$ is normally called a stock externality in fisheries economics.

For a three-player coalition structure interacting with a player standing-alone, and for a twoplayer coalition interacting with another two-player coalition, equation (8) implies solving two equations (one for each coalition structure) with two unknowns. For a two-player coalition interacting with two players standing-alone we obtain three equations with three unknowns. If all four players are stand-alone, equation (8) represents four equations with four unknowns. Thus, the solution to the profit maximization problem for any possible coalition structure can be written as $h_{s}^{*}$. By inserting the actual value of stock size (in 2011) and $h s^{*}$ into the objective function, we obtain the coalitional value for each possible coalition structure, $\pi_{S} *$ (apart from the grand coalition).

Now we use the first-order conditions in equations (6) and (8) to undertake three different comparisons of the harvest levels. First, for a given number of players in a coalition structure, we compare the effect of having low and high marginal costs by using equation (8). From equation (8), low marginal costs imply that $\frac{\partial P}{\partial h} h_{S}+P(h)$ must be low (since the first-order condition must always hold) and here it is important that $\frac{\partial P}{\partial h}<0$. Thus, if the marginal costs are low, $P(h)$ must be low and/or $\frac{\partial P}{\partial h} h_{S}$ must be numerically low, leading to the result that $h_{S}$ must be high. The opposite results hold if the marginal costs are high.

Second, we consider the effect of entering coalitions, assuming that more players in a coalition imply that the marginal cost decrease. From equation (8), it follows that $P(h)$ decreases and/or the numerical value of $\frac{\partial P}{\partial h} h_{S}$ decreases (for the first-order condition to hold). Thus, more players in a coalition imply that the harvest by all members of the coalition increase.

Finally, by using equations (6) and (8) we compare the harvest levels of the grand coalition and a three-player coalition. The inclusion of the term $\frac{\partial C}{\partial M} \frac{\partial M}{\partial h}$ in equation (6) but not in 
equation (8) tends to reduce the harvest of the grand coalition compared to a three-player coalition structure. This effect arises because the grand coalition takes the resource restriction into account while the three-player coalition does not. Alternatively stated, an optimal stock size is obtained with a grand coalition while a three-player coalition takes the stock size as given (exogenous parameter). However, an opposite effect tends to increase the harvest level of a grand coalition compared to a three-player coalition, because we assume that the marginal cost is reduced when entering a grand coalition. In this paper, we assume

that the effect of $\frac{\partial C}{\partial M} \frac{\partial M}{\partial h}$ dominates the effect of the decrease in the marginal costs, so the harvest level is reduced when moving from a three-player coalition to a grand coalition.

\section{Functional forms and parameter values}

In order to identify the coalitional values for the mackerel fishery in the Northeast Atlantic Sea we must estimate demand, cost and growth functions. This section presents the results and main assumptions in relation to our estimations while details on the data can be found in an appendix which is available on-line at http://ifro.ku.dk/mackerel-appendix.

\subsection{Demand function}

To keep the estimation as simple as possible, we assume that the prices and quantities of other fish species/goods (substitutes and complements) are not included in the demand function. A number of demand studies for fish species have included the prices and quantities of other fish species with mixed results (see Asche et al., 2005 for an overview).

As mentioned in section 2.1 we also assume that the harvest of the players are perfect substitutes. One implication of this assumption is that only one price for mackerel exist on a common market in the EU, NO, IC and the FI, implying that the markets is perfectly integrated. A large amount of market integration studies for fish products exist (a classical paper on market integration is Squires et al., 1989 while Asche et al., 2005 contains an overview of selected studies). A common approach in the literature on market integration is to test whether there exist a statistically significant relationship between at least two prices by using co-integration. In relation to our paper, one argument is that the fish markets in IC and the FI are not perfectly integrated with the markets in the EU and NO and since IC and the FI is 
geographically separated from the other regions. However, Tveteras et al. (2014) show that the markets for fish products (including mackerel) in Western Europe (including IC and the FI) are highly integrated and that a common price exist on all potential sub-markets . Thus, it seems reasonable to assume that a common market for mackerel in the EU, NO, IC and the FI exists.

Another issue arising with perfectly integrated markets is that the assumption seems to be less useful when analysing the mackerel crisis. Specifically, the EU and NO banned the landings of vessels from IC and the FI in their harbours and by assuming a perfectly integrated market, this policy action is not taken into account. However, we assume that IC and the FI have access to another market yielding the same price as in the common market in the EU and NO (see Tveteras et al., 2014). Thus, a common demand function for the EU, NO, IC and the FI provide an approximation for the relevant demand function when IC and the FI does not have access to the markets in the EU and NO.

Based on Anon (2017a, b, c, d), we are able to identify a time series for the price and quantity of mackerel on a common market covering the time period from 1999 to 2016, and these data is used to estimate a demand function (see on-line appendix, section A.3). We have been estimating several specifications of the demand function, including an iso-elastic function and a specification derived from a Cobb-Douglas function. When using ordinary least square (OLS), a standard linear function gives the best fit judged by the $\mathrm{R}^{2}$ value and the $\mathrm{t}$-statistics. The linear demand function is specified as:

$$
P=a-b h
$$

where $h$ is the aggregated quantity of mackerel demanded in the EU, NO, IC and the FI; $P$ is the consumer price; $a$ is a intercept or reservation price; $b$ is the slope of the demand function.

Note that when estimating equation (9), the usual identification problem arise (see Johnston, 1984). By having a time series for the price and quantity, it is not possible to identify whether an observation result from shifts in the demand or supply function. A common solution to this problem is to have a separate variable that identifies the demand and supply functions and then estimate these two functions as simultaneous equations. However, in fisheries 
economics, it is common to estimate demand functions without considering supply functions, a procedure that we follow (see Asche et al., 2005 for a discussion).

In Table 1, we summarize the results of the estimation of the linear demand function on a common market for mackerel in the EU, NO, IC and the FI.

Table 1: Estimation of the common demand function for mackerel.

Both the intercept and the slope of the demand function are significant and have the expected sign (see Table 1). The $\mathrm{R}^{2}$ value is reasonably high, so the model explains a main part of the variation in the price data, but the value of the slope parameter, $b$, indicates that the demand function is very flat compared to other demand studies (see Asche et al., 2005 for an overview). This is probably because we estimate a demand function on a large common market in the EU, NO, IC and the FI. A flat demand function suggests that an increase in harvest by forming coalitions leads to a small reduction in the marginal revenue. Thus, for a given marginal cost reduction we expect that the required change in harvest level to fulfil equation (8) will be large. Below we refer to the estimation results in Table 1 as our benchmark case.

However, two potential problems arise with the estimation of the demand function in the benchmark case. First, the Durbin-Watson test (DW) indicates that a problem with autocorrelation arise but estimation of equation (9) with general least square (GLS) gives poor results. Second, the estimated parameters is (as always) subject to statistical uncertainty and the size of this uncertainty can be seen from the standard errors in Table 1. To address these two problems, we have been conducting sensitivity analyses by varying the estimated parameters in the demand function and the results of these analyses are reported in section 4.4.

\subsection{Cost functions}

When estimating a cost function for each possible coalition structure we impose a singlespecies assumption such that the harvest or stock size of other fish species does not influence the cost of harvesting mackerel. If the harvesting of other species influences the harvesting 
cost, economic interactions arise. A classic paper on economic interaction is written by Anderson (1975).

Based on the single-species assumption, the following cost function provides the best fit for all possible coalition structures:

$$
C_{S}\left(h_{S}, x\right)=\frac{c_{S}\left(h_{S}\right)^{2}}{x}
$$

where $c_{S}$ is a cost parameter that differs among coalition structures. Equation (10) is a variant of the quadratic cost function normally used in non-cooperative game theory (see, e.g., Friedman, 1979).

Based on Anon (2017a, b, c), we have calculated time series for the total economic costs when the EU, NO and IC is standing-alone for the period between 1997 and 2016 (see on-line appendix, section A.4). No cost information exists for the FI, but the fleet structure for the Northeast Atlantic mackerel fishery is similar in IC and the FI (see Jensen et al., 2018 and ICES, 2017). We have, therefore, identified a time series for the total costs of the FI by correcting the cost observations for IC with the relative aggregated harvest share of the FI in relation to IC from ICES (2017) (see on-line appendix, Table A.1.). ICES (2017) also contains information about the stock size which is used to estimate equation (10), and Anon (2017a, b, c) provides a relevant time series for the harvest by the EU, NO and IC. The observations for the harvest of the FI are identified by using the same procedure as for the costs. To estimate stand-alone cost functions defined in equation (10), we calculate a time series for $\frac{\left(h_{S}\right)^{2}}{x}$ and then OLS is used to estimate the cost function.

We also need cost functions for every possible coalition structure (apart from when all players stand-alone) and it seems natural to aggregate the stand-alone cost functions to obtain these. However, this procedure cannot be used with the cost specification in equation (10). To explain this, we must distinguish between a public and private good. Now it is important that cost functions are aggregated vertically for public goods and horizontally for private goods. In our cost function, we included both a public good (or input), $x$, and a private good, $h$, so aggregation is not possible to undertake in a meaningful way. Thus, we use the following procedure to estimate cost functions for every coalition structure. As described 
above, we have data on the cost of harvesting mackerel and the harvest when all players stand-alone. When analysing a given coalition structure, we summarize the total cost of mackerel and the harvest for all coalition members. Thus, we obtain observations for the total cost of harvesting mackerel and the harvest for a given coalition structure, and by using the stock size, we estimate coalition cost functions. We have used OLS to estimate equation (10) for all possible coalition structures.

The results of the estimations for all possible coalition structure are presented in Table 2 .

Table 2: Estimation of cost functions for all possible coalition structures.

All the estimated values of $c_{S}$ are significant and $\mathrm{R}^{2}$ is reasonable high for all possible coalition structures (see Table 2). We refer to the estimation results summarized in Table 2 as our benchmark case.

We have been trying to estimate cost functions with several different potencies on $h_{S}$ and $x$. Compared to the specification in equation (10), the maximum value of $\mathrm{R}^{2}$ in these functions is 0.78 so we prefer to use the results in Table 2 below. Furthermore, for the case where all players stand-alone we have been trying to estimate cost functions without including the stock size $\left(C_{S}\left(h_{S}, x\right)=c_{S}\left(h_{S}\right)^{2}\right)$ corresponding to an assumption about a schooling fishery. For a schooling fishery, $\mathrm{R}^{2}$ varies between 0.62 and 0.71 and, therefore, the results in Table 2 imply that mackerel in the Northeast Atlantic Sea is a search fishery contrary to what is commonly argued.

From Table 2, the ranking of the stand-alone cost parameters is as follows: $c_{I C}<c_{F I}<c_{E U}<c_{N O}$. Thus, IC and the FI have the lowest stand-alone cost parameters while the EU and NO have the highest parameters. An identical ranking of parameters occurs for two- and three-player coalition structures. Here, coalition structures involving IC and the FI have the lowest cost parameters, while coalitions involving the EU and NO have higher parameters. The ranking of the cost parameters imply that the harvest is highest for coalition structures (including when the players stand-alone) involving IC and the FI. One reason for the high cost parameter for $\mathrm{NO}$ is that the fleet segment included in the analysis is Norwegian purse seiners (see on-line appendix, section A.2). In fisheries economics it is well-known that Norwegian purse seiners 
have higher total cost than other fleet segments (see, e.g., Jensen et al., 2018). Compared with other parameter estimates in the literature using the same cost specification, the stand-alone cost parameters in Table 2 are low, likely because mackerel has a low marginal stock cost (see Arnason et al., 2000 and Jensen and Vestergaard, 2002),.

When moving from a one-player to a two-player coalition structure, the cost parameters decrease considerably, implying a large increase in harvest (see Table 2). However, when moving from a two-player to a three-player coalition structure the decrease in the cost parameter is small, leading to a small increase in the harvest. When moving from a threeplayer coalition structure to a grand coalition, the decrease in the cost parameter is also small, so the tendency to increase the harvest levels when moving to a grand coalition is of minor importance (see section 2.3).

Note that the estimation results in the benchmark case in Table 2 are subject to the same uncertainty as for the demand function (see section 3.1). Thus, statistical uncertainty and autocorrelation makes it useful to conduct sensitivity analyses by varying the cost parameter of each possible coalition separately, and the results of these are reported in section 4.4. However, estimation of the cost function is also subject to a more fundamental data uncertainty problems due to, at least, two facts: 1. For each coalition structure (apart from when the players stand-alone), cost data is derived by aggregating cost observations for each player; 2. For the FI hypothetical cost data is used. To address cost data uncertainty we have been undertaking a sensitivity analysis where all cost parameters of coalitions involving a player is varied and the result of these analyses is also reported in section 4.4.

\subsection{Natural growth and biological response functions}

In the case of a grand coalition, we also need a natural growth function, $G(x)$. Here we adopt a single-species assumption where the natural growth of mackerel does not depend on the stock size of other fish species and this assumption imply that no biological interactions arise. Concerning the functional form of the growth function, several possibilities exist, including logistic and Ricker functions (see Conrad and Clark, 1991). In the following empirical analysis of the mackerel crisis, we use a logistic growth function given by:

$$
G(x)=r x\left(1-\frac{x}{K}\right)
$$


where $r$ is the intrinsic growth rate and $K$ is the carrying capacity.

To estimate equation (11) we use a time series for the total biomass (the stock size) from ICES (2017). Based on this series and a time series for the aggregated harvest of the EU, NO, IC and the FI from ICES (2017), we can identify a time series for the natural growth (see on-line appendix, section A.5). The time series for the stock size and natural growth cover the period from 1984 to 2016 and are used to estimate equation (11). Here OLS is used and the results are summarized in Table 3.

Table 3: Estimation of a growth function.

Both $r$ and $K$ are significant and the $\mathrm{R}^{2}$ value is high (see Table 3). The estimated value of $r$ is reasonable compared to the estimates for other similar fisheries (see Arnason et al., 2000). However, the estimated parameter for the carrying capacity cannot be compared between fisheries because it is a measure of the maximum size of a fish stock without any harvest. We refer to the estimation results for the natural growth function summarized in Table 3 as our benchmark case.

To test the logistic specification in equation (11) we have also estimated a Ricker growth function. A Ricker growth function is a logistic function that is skewed to the right and Tahvonen et al. (2018) and Skonhoft and Gong (2016) show that such a function is consistent with a Beverton-Holt specification, which is based on an assumption about different growth functions for each age-class of a fish species. However, the Ricker and logistic growth function gives similar results and, therefore, we choose to use the symmetric logistic growth function to simplify the empirical analysis.

However, from the values of DW we see that a problem with autocorrelation arise but estimating equation (11) with GLS gives poor results. Furthermore, from the standard errors of $r$ and $K$ in Table 3 it is clear that the estimated parameters are subject to considerable statistical uncertainty. To address these problems, we have been undertaking sensitivity analyses by varying the intrinsic growth rate and carrying capacity and the result of these is reported in section 4.4 . 
Based on the logistic growth function, we can also derive an expression for $M(h)$ which is used when players form a grand coalition (see section 2.2). By using equation (11), equation (2) becomes:

$$
-\frac{r x^{2}}{K}+r x-h=0
$$

Solving equation (12) for $x$ and using the largest root gives:

$$
x=M(h)=\frac{k r+\left(k^{2} r^{2}-4 k r h\right)^{0.5}}{2 r} .
$$

We can insert the estimated values of $r$ and $K$ from Table 3 into equation (13) to reach a numerical value for both $x=M(h)$ and $\frac{\partial M}{\partial h}$.

The growth function is used when identifying the value of the grand coalition, while the stock size is treated as an exogenous parameter when investigating other coalition structures (section 2.3). To measure this exogenous parameter, we use the stock size of mackerel in the Northeast Atlantic Sea in 2011 because the effects of the mackerel crisis is clear in that particular year. The stock size of mackerel in 2011 is equal to 4203 (1000 tons) (see on-line appendix, Table A.1 ).

\section{Results}

\subsection{Coalitional values}

We can calculate the coalitional values introduced in section 2 by using the functional forms and parameter values for the benchmark case from section 3. Formally, the coalitional values are defined in the following way. For all coalition structures, $\sigma$, and coalitions, $S \in \sigma$, let $v_{\sigma}(S)=\pi(S)$ be the profit for coalition $S$ for the mackerel fishery in the Northeast Atlantic Sea for a given coalition structure, $\sigma$ (defined in equation (3) and/or (7)). Since we have four players, the following possible coalition structures exist: 1 . One grand coalition; 2 . One coalition structure where all four players stand-alone; 3. Four structures where a three-player coalition interacts with a player standing-alone; 4 . Three structures where a two-player 
coalition interacts with another two-player coalition; 5 . Six coalition structures where a twoplayer coalition interacts with two players standing-alone.

The coalitional values for the benchmark case are summarized in Table 4 .

Table 4: Estimation of coalitional values for the benchmark case.

From Table 4 we see that the ranking of the coalitional values when all players stand-alone follow the ranking of the stand-alone cost parameters in Table 2. IC and the FI obtain the highest coalitional value while the EU and NO obtain a lower value. This ranking also holds when players form coalitions. Specifically, coalitions involving IC and the FI obtain the highest value while coalitions involving the EU and NO obtain a lower value. Moving from a oneplayer to a two-player coalition structure generates a large increase in the coalitional values because of a large decrease in the cost parameter (see Table 2). However, moving from twoplayer to three-player coalition structures only has a small effect on the coalitional value because the cost decrease from this change is small. Moving from a three-player coalition structure to a grand coalition also results in a small change in the coalitional value. This result holds despite the fact that the optimal stock size is used to find the value of the grand coalition while the actual stock size in 2011 is used to find the value of a three-player coalition.

\subsection{Internally stable coalition structures}

Based on the coalitional values in Table 4 we can identify coalition structures, which are internally stable in the sense that no coalition in the structure has incentive to split up. Formally, the notion of internal stability is defined in the following way. A coalition structure, $\sigma=\left\{S_{1}, \ldots \ldots, S_{k}\right\}$ where $\sigma$ is a partition of $N$, is internally stable if there is no $S \in \sigma$ for which there exists a $S^{\prime} \subset S$ such that $v\left(S^{\prime}\right)+v\left(S \backslash S^{\prime}\right)>v(S)$. Note that the singleton (all players standalone) is internally stable by definition since no sub-coalition can be formed. From the definition of an internally stable coalition, two observations are important: 1 . There may exist several internally stable coalition structures for a given set of players; 2 . We do not try to explain how coalitions are actually formed but only identify internally stable coalitions.

\subsection{Benchmark case}


Consider the coalitional values in the benchmark case in Table 4 and let us identify internally stable coalition structures. We begin by investigating whether the grand coalition is an internally stable structure. It is easy to see that this is not the case. As an example, in the structure [\{EU, NO, IC $\} ;\{\mathrm{FI}\}]$, the values of each coalition are 548 and 259 respectively. Since this adds up to 807, there is no way to allocate the value of the grand coalition (784) such that none of the two coalitions, $\{\mathrm{EU}, \mathrm{NO}, \mathrm{IC}\}$ or $\{\mathrm{FI}\}$, will gain from non-cooperation. Now the structure $[\{\mathrm{EU}, \mathrm{NO}, \mathrm{IC}\} ;\{\mathrm{FI}\}]$ is not internally stable either. For example, in the coalition structure [\{EU, NO\}; $\{\mathrm{IC}\} ;\{\mathrm{FI}\}]$, the value of [\{EU, NO\}; $\{\mathrm{IC}\}]$ is 569 which exceeds 548 which is the value that the EU, NO and IC gets in the structure [\{EU, NO, IC $\} ;\{\mathrm{FI}\}]$. Thus, one of the subcoalitions gain from non-cooperation. In a similar way, it is easy to show that none of the remaining three-player coalition structures is internally stable. Turning to two-player versus two-player coalitions, consider [\{EU, NO\}; $\{\mathrm{IC}, \mathrm{FI}\}]$. This coalition is clearly not internally stable since, for example, the EU and NO gets on 329 in the structure [\{EU\}; $\{\mathrm{NO}\} ;\{\mathrm{IC}, \mathrm{FI}\}]$, which exceeds the coalitional value of 298 in the structure [\{EU, NO\}; $\{\mathrm{IC}, \mathrm{FI}\}]$. By following the same line of argumentation, we can show that the only internally stable coalition structure (apart from the singleton) is [\{IC, FI $\} ;\{E U\} ;(N O\}]$.

Based on the notion of internal stability we get that IC and the FI have an incentive to cooperate while the EU and NO have an incentive to act alone during the mackerel crisis. Let us now provide an economic explanation for these result and this is done in two steps. First, coalition structures involving IC and the FI have the lowest cost parameters, while structures involving the EU and NO have the highest cost parameters (see Table 2). Thus, if a two-player coalition structure shall be internally stable, it must be between IC and the FI because this coalition generates the highest value of each player. Second, moving from a one-player to a two-player coalition structure generates a large increase in the coalitional values (due to a large decrease in the costs), while moving from a two-player to a three-player coalition structure only generated a small increase in the coalitional values (due to a small decrease in the cost parameter). Thus, it seems reasonable to postulate that a two-player coalition will be formed and, in total, the only potentially internally stable coalition structure in the benchmark case is $[\{\mathrm{IC}, \mathrm{FI}\} ;\{\mathrm{EU}\} ;\{\mathrm{NO}\}]$.

Finally, let us use our results to answer the first research question from section 1.3. With the result that $[\{\mathrm{IC}, \mathrm{FI}\} ;\{\mathrm{EU}\} ;(\mathrm{NO}\}]$ is the only internally stable coalition we are able to rationalize 
why a grand coalition was not formed between the players during the mackerel crisis. However, we are unable to rationalize the following facts: 1 . Why the EU and NO had a bilateral agreement for the period between 2010 and 2014; 2. Why IC and the FI acted independently until 2014; 3. Why the FI entered an agreement with the EU and NO in 2014 while IC still acted alone. However, as mentioned in section 3 considerable statistical and data uncertainty exist in relation to the parameter estimates. Thus, to make a robust investigation of whether we can rationalize the outcome during the mackerel crisis, we must undertake sensitivity analyses. The results of these are presented below.

\subsection{Sensitivity analyses}

In this section, we report the results of a number of sensitivity analyses that has been conducted by varying the parameter used in the benchmark case. Specifically, two kinds of sensitivity analyses have been conducted: 1 . We have varied each parameter in the demand, growth and coalition cost functions separately in order to address problems with statistical uncertainty and autocorrelation; 2 . We have varied the parameters in all cost functions for coalitions involving a player to address problems with data uncertainty. In both cases, we vary the parameter estimates with +/- 1.96 times the standard derivation of the estimated parameters. This variation is selected because it generates upper and lower bounds on the parameter estimates within which the true value lies with a 95\% probability. For each parameter variation, we discuss the implications of varying the parameters for both the coalitional values and the internally stable coalition structures in the following subsections. In this way, we can address both the first and second research question mentioned in section 1.3.

\subsubsection{The demand function}

In Table 5, the coalitional values and internally stable coalitions obtained when varying the intercept and slope of the demand function are reported.

Table 5: Sensitivity analysis for the parameters in the demand function.

Let us first look at the coalitional values obtained when varying the intercept in the demand function. From Table 5 we obtain that a decrease in the intercept leads to a decrease of all 
coalitional values while an increase in the intercept generate an increase of all values. This result seems natural because a decrease in the intercept is identical to a downwards shift in the demand function while an upwards shift in the function occur with an increase in the intercept. An identical result is obtained when varying the slope of the demand function. Here a decrease in the slope implies that the demand function becomes flatter which increases all coalitional values. An opposite result is obtained when the demand function becomes steeper. By comparing the coalitional values for variations in the intercept and the slope, we see that the former has a larger effect on the coalitional values than the latter. This may be due to differences in the size of the standard derivation of the estimated parameters (see Table 1) but, alternatively, the result might indicate that variation in the intercept has a larger influence on the coalitional values variations in the slope.

Turning to internally stable coalition structures, we see that $[\{I C, F I\} ;\{E U\} ;\{N O\}]$ is still the only internally stable structure in the game. Thus, even when varying the parameters in the demand function we are unable to rationalize important aspects of the actual coalition formation during the mackerel crisis. The explanation for this result is that varying the parameters in the demand function affects the values of all coalitions in a similar way implying that the internally stable structures does not change.

\subsubsection{The growth function}

Table 6 summarize the results obtained when varying the intrinsic growth rate and carrying capacity in the growth function.

Table 6: Sensitivity analysis for the parameters in the growth function.

To understand the results in Table 6 it is important to remember that a natural growth function is only used when finding the value of the grand coalition. Thus, for all other coalitions than $[\{\mathrm{EU}, \mathrm{NO}, \mathrm{IC}, \mathrm{FI}\}]$, the coalitional values is unaffected by the parameter variation. As shown in Table 6, a decrease in the intrinsic growth rate generates a decrease in the value of the grand coalition while an increase in $r$ implies an increase in the coalitional value of $[\{\mathrm{EU}, \mathrm{NO}, \mathrm{IC}, \mathrm{FI}\}]$. This result is obvious since an increase in $r$ implies a larger growth of the mackerel stock size while a decrease in $r$ is identical to a decrease in the fish stock. For the carrying capacity, we mentioned in section 3.3 that this is a measure for the size of the 
fishery. Thus, a decrease in $K$ implies that the value of [\{EU, NO, IC, FI $\}]$ decrease while an increase in $K$ generates an increase of the value of the grand coalition. By comparing the value of the grand coalition with variations in $r$ and $K$, we see that the variation of the values is much larger for the latter than for the former. This may be due to differences in the standard errors of the estimated parameters (see section 3.3) but an alternative explanation is that variations in the carrying capacity matters more for the value of the grand coalition than variations in the intrinsic growth rate.

Turning to the internally stable coalition structures the only stable structure is still [\{IC, FI $\}$; $\{\mathrm{EU}\} ;\{\mathrm{NO}\}]$. Thus, even though an increase in $r$ and $K$ imply an increased value of the grand coalition, [\{EU, NO, IC, FI\}], is still not internally stable.

\subsubsection{The cost functions}

\subsubsection{Grand coalition}

Table 7 shows the results of varying the cost parameter for the grand coalition while keeping the cost parameters for all other coalitions unchanged.

Table 7: Sensitivity analysis for the parameter in the cost function of the grand coalition.

Since only the cost parameter for the grand coalition is varied, the results is similar to those for the natural growth function (see section 4.4.2). Specifically, from Table 7 we see that a decrease in the cost parameter for [ $\{\mathrm{EU}, \mathrm{NO}, \mathrm{IC}, \mathrm{FI}\}]$ leads to an increase in the value of the grand coalition, while an increase in the cost parameter has the opposite effect. Since only the value of the grand coalition is affected, a decrease in the cost parameter may potentially lead to internal stability of the grand coalition. However, for a cost parameter decrease, the increase of the value of the grand coalition is so small that [\{IC, FI $\} ;\{E U\} ;\{N O\}]$ is still the only internally stable coalition. The fact that the grand coalition is not internally stable is consistent with the actual behaviour of the players during the mackerel crisis.

\subsubsection{Three-player coalitions}

The results of varying the cost parameters for all three-player coalitions separately are reported in Table 8. 
Table 8: Sensitivity analysis for the parameters in the cost functions of three-player coalitions.

Because only the three-player coalition cost parameters are varied, the values of all other coalition structures are unaffected. Naturally enough, a cost parameter decrease for a threeplayer coalition implies that the value of this coalition is increased while the opposite arises with a cost parameter increase (see Table 8). Furthermore, a cost parameter decrease implies an increase in the harvest while a decrease in the harvest occurs with a cost parameter increase. Note here that a three-player coalition and the player standing-alone interacts in a non-cooperative Cournot-Nash game in the quantities. Thus, a decrease (increase) in the harvest of the three-player coalition implies an increase (decrease) in the harvest (and coalitional value) of the player standing-alone.

Turning to internally stable coalitions, we see from Table 8 that when decreasing the cost parameters (and increasing the coalition value) for all three-player coalitions involving NO, these coalitions also become internally stable. However, all other variations in the cost parameter for three-player coalitions does not affect the internally stable coalition structure represented by $[\{\mathrm{IC}, \mathrm{FI}\} ;\{\mathrm{EU}\} ;\{\mathrm{NO}\}]$. This result arise because two-player coalitions involving NO have a high cost parameter (and low coalitional value). Thus, three-player coalitions involving NO become internally stable since there are no incentive to leave these. This is not the case for structures involving the EU, since two-player coalitions involving the EU have a lower cost parameter. Note that the internally stable coalition structures [\{EU, NO, IC $\} ;\{F I\}]$ and $[\{\mathrm{EU}, \mathrm{NO}, \mathrm{FI}\} ;\{\mathrm{IC}\}]$ involve cooperation between the EU and NO as was observed during the mackerel crisis between 2010 and 2014. Furthermore, the internally stable coalition structure [ $[\mathrm{EU}, \mathrm{NO}, \mathrm{FI}\} ;\{\mathrm{IC}\}]$ is consistent with the actual behaviour of the players after 2014 . Thus, reducing the cost parameter for three-player coalitions involving NO implies that we are partly able to rationalize the actual behaviour of the players during the mackerel crisis.

\subsubsection{Two-player coalitions}

The coalitional values obtained when varying the cost parameter for each two-player coalition separately is summarized in Table 9.

Table 9: Sensitivity analysis for the parameters in the cost functions of two-player coalitions. 
Note, first, that the values of the grand coalition, all three-player coalitions and all players standing alone are unaffected with separate variations in the cost parameter for two-player coalitions. Now decreasing (increasing) the cost parameter for a two-player coalition will: 1. Increase (decrease) the value of the coalition when playing a non-cooperative Cournot-Nash game in the quantities against another two-player coalitions; 2 . Increase (decrease) the value of the coalition when playing a non-cooperative Nash game against two players standingalone; 3. Decrease (increase) the harvest and value of the complementary coalition due to strategical interaction.

Looking at internally stable coalitions four main results arise. First, when decreasing the cost parameter for $\{\mathrm{EU}, \mathrm{NO}\}$, two additional coalitions represented by [\{EU, NO $\} ;\{\mathrm{IC}, \mathrm{FI}\}]$ and [\{EU, NO\}; $\{\mathrm{IC}\} ;\{\mathrm{FI}\}]$ become internally stable. The fact that coalitions between the EU and NO become internally stable is not surprising since the cost parameter of a coalition between these two players are decreased. Note that the structure [\{EU, NO $\} ;\{\mathrm{IC}\} ;\{\mathrm{FI}\}]$ represents the actual outcome during the mackerel crisis between 2010 and 2014. Second, when decreasing the cost parameter of $\{\mathrm{EU}, \mathrm{IC}\}$, the coalition structure $[\{\mathrm{EU}, \mathrm{IC}\} ;\{\mathrm{NO}\} ;\{\mathrm{FI}\}]$ also becomes internally stable, but this result does not correspond to the actual outcome during the mackerel crisis. Third, when the cost parameter of a coalition involving NO and IC is decreased $[\{\mathrm{NO}, \mathrm{IC}\} ;\{\mathrm{EU}\} ;\{\mathrm{FI}\}]$ also becomes internally stable but this outcome is neither observed during the mackerel crisis. Finally, when the cost parameter of $\{\mathrm{IC}, \mathrm{FI}\}$ is increased one additional internally stable coalition structure is [\{NO, IC, FI $\} ;\{E U\}]$. The explanation for this result is that it becomes profitable to include NO in a coalition because the cost of forming a two-player coalition between IC and the FI has been increased. It is not possible to include the EU in an internally stable coalition because the EU has a low stand-alone cost implying that this player will leave the three-player coalition. However, a coalition involving NO, IC and the FI is not observed during the mackerel crisis.

\subsubsection{Standing-alone}

Table 10 shows the results obtained when varying each player's stand-alone cost parameter.

Table 10: Sensitivity analysis for the parameters in the cost functions when the players standalone. 
Note that the values of all other coalition structures than the singleton are unchanged when varying the stand-alone cost parameters. Naturally enough, Table 10 show that when the cost parameter for a player standing-alone increases (decreases), the coalitional value decreases (increases). Furthermore, the harvest of the player also decrease (increase), so the harvest and value to the complementary coalitions increase (decrease) because of strategic interaction between the coalitions.

Looking at the internally stable coalition structures an increase in the stand-alone cost parameter of both the EU and IC implies that the coalition structure $[\{\mathrm{EU}, \mathrm{IC}\} ;\{\mathrm{NO}\} ;\{\mathrm{FI}\}]$ also becomes internally stable. The explanation for this result is that an increase in the stand-alone cost parameter for these two players generate a low value of standing-alone so the benefit of leaving a two-player coalition decrease. However, a coalition involving the EU and IC is not observed during the mackerel crisis.

\subsubsection{Cost data uncertainty}

Table 11 shows the coalitional values obtained when varying all cost parameters for coalitions involving a player.

Table 11: Sensitivity analysis for the parameters in all coalition cost functions involving a player.

When increasing the cost parameter for all coalitions involving a player, the values of these coalitions (including when the player stand-alone) decrease while the opposite happens with a cost parameter decrease. Furthermore, the value of complementary coalitions (apart from the grand coalition) increase because of strategic interaction.

Regarding internally stable coalitions, we obtain two main results. First, when decreasing all cost parameters for coalitions involving the $\mathrm{EU},[\{\mathrm{EU}, \mathrm{IC}\} ;\{\mathrm{NO}\} ;\{\mathrm{FI}\}]$ becomes additional internally stable coalition structure. This result arises because a cost parameter decrease for the EU makes it more profitable for IC to form a coalition with this player. However, a coalition involving the EU and IC is not observed during the mackerel crisis. Second, when decreasing the cost parameters for all coalitions involving NO, all three-player and two-player coalitions with the player aso becomes internally stable. The explanation for this result is that 
with a cost parameter decrease for NO entering coalitions with this player becomes more profitable. Thus, by varying the cost parameter for all coalitions involving NO we are able to rationalize 1 . Why the EU and NO entered an agreement during the mackerel crisis between 2010 and 2014; 2. Why the EU, NO and the FI cooperated from 2014 and onwards.

\subsubsection{Summary of the sensitivity analyses}

Let us conclude this section by providing answers to the two research questions from section 1.3. Regarding rationalizing the outcome during the mackerel crisis (research question one) we obtain three main results: 1 . Forming a grand coalition is never beneficial and this is consistent with the actual behaviour of the players during the mackerel crisis; 2 . When decreasing the cost parameter of a two-player coalition between the EU and NO or the cost parameter of all coalitions involving NO, the actual coalition formation during the mackerel crisis between 2010 and 2014 become internally stable; 3 . When decreasing the cost parameter of a three player coalition involving the EU, NO and the FI or the cost parameter for all coalitions involving NO, the actual behaviour during the mackerel crisis from 2014 and onwards becomes internally stable. Thus, by undertaking sensitivity analyses, we are partly able to rationalize the actual behaviour of the players during the mackerel crisis.

Turning to the economic factors potentially affecting the outcome during the mackerel crisis (research question two), we are able to explain the variations in the coalition values by using standard fisheries economic theory. Furthermore, varying the parameters in the demand and growth function does not affect which coalition structures that is internally stable. For the demand function, the explanation for this result is that the parameters in this function affect the value of all coalitions in a similar way. However, the parameters in the growth function only affect the value of the grand coalition so we can conclude that a grand coalition is unlikely to be formed during the mackerel crisis. However, varying the parameters in the cost functions may potentially affect which coalition structures that are internally stable because a separate cost function is estimated for each possible coalition. Of particular importance is a decrease in the cost parameters for coalitions involving NO, because this player has relatively high total costs in the benchmark case.

\section{Conclusion}


In the present study, we investigate the mackerel crisis in the Northeast Atlantic Sea by using game theory. Two main facts characterized the mackerel crisis: 1. Between 2010 and 2014, the EU and NO cooperated while IC and the FI acted alone; 2. From 2014 and onwards, the EU, NO and the FI cooperated while IC acted alone. An empirical application of game theory requires that the values of all coalition structures (the coalitional values) involving the EU, NO, IC and the FI must be identified and we use a fisheries economic model for this purpose. For the grand coalition, the aggregated profit are maximized subject to a resource restriction. The resource restriction is disregarded for all other coalition structures and here the coalitions play a non-cooperative Cournot-Nash game in quantities against each other. To identify the coalitional values, a full empirical model is specified including demand, growth and cost functions. For the FI we do not have any cost data, but the fleet structure for fishing mackerel in the Northeast Atlantic Sea is similar in IC and the FI; thus, cost information for IC are adjusted to obtain cost observations for the FI. In this paper, we address the following two research questions: 1 . Can we rationalize the outcome during the mackerel crisis with our model; 2. Which economic factors has a potential influence on the coalition formation during the mackerel crisis. To answer these two research questions we identify coalition structures that are internally stable in the sense that no coalition of players has an incentive to leave.

Regarding the first research question, we investigate a benchmark case, and we are able to rationalize why a grand coalition was not established during the mackerel crisis. However, we are unable to rationalize: 1 . Why the EU and NO had a bilateral agreement for the period between 2010 and 2014; 2. Why IC and the FI acted independently between 2010 and 2014; 3. Why the FI entered an agreement with the EU and NO in 2014. However, this result may be due to statistical and data uncertainty so we have been undertaking a number of sensitivity analysis. With these sensitivity analyses, we are partly able to rationalize the outcome during the mackerel crisis. Specifically, we obtain that: 1. A decrease in the cost parameter for a coalition involving the EU and NO or the cost parameter for all coalitions involving NO imply that a two-player coalition between the EU and NO becomes internally stable; 2 . A decrease in the cost parameter for a coalition involving the EÙ, NO and the FI or the cost parameter for all coalitions involving NO imply that a three-player coalition between the EU, NO and the FI becomes internally stable. 
The results of the sensitivity analyses can also be used to provide an answer to the second research question. Here we are able to show that varying the parameter values in the demand function will not affect which coalition structures are internally stable because the parameters in this function affect the value of all coalitions in a similar way. Furthermore, the parameters in the growth function does not affect which coalition structures that is internally stable. In our model a growth function is only incorporated in the model for the grand coalition so this result indicate that it is unlikely that a coalition between all players will be formed. However, varying the parameters in the cost function may potentially affect which coalition that is internally stable because separate cost functions is estimated for each structure. Specifically, a decrease in the cost parameters for coalitions involving NO imply that coalitions involving this player becomes internally stable because this player has relatively high total costs in the benchmark case.

An obvious extension of the analysis presented in this paper is to construct a dynamic model for the mackerel fisheries in the Northeast Atlantic Sea. This future research would also enable a more explicit analysis of the implications of climate change and how it would influence the cost of harvesting mackerel. 


\section{Literature}

Anderson, L.G. (1975): Analysis of Open-Access Commercial Exploitation and Maximum Economic Yield in Biologically and Technologically Interdependent Fisheries, Journal of Fisheries Research Board of Canada, 32, pp. 1825-1842.

Anon (2017a): UK Fisheries Statistics, United Kingdom Government.

Anon (2017b): Profitable Survey on the Norwegian Fishing Fleet, Norwegian Directory of Fisheries, Oslo.

Anon (2017c): Statistics Iceland, Reykjavik.

Anon (2017d): Fiskeristatistisk Årbog, Copenhagen.

Armstrong, C.W. and Flaaten, O. (1991): The Optimal Management of Transboundary a Fish Resource - The Arctic-Norwegian Cod Stock in Arnason, R. and Bjørndal (ed): Essays in the Economics of Migratory Fish Stocks, Springer, Berlin.

Arnason, R., Sandal, L.K, Steinshamn, S.I., Vestergaard, N., Agnarson, S. and Jensen, F. (2000): Comparative Evaluation of the Cod and Herring Fisheries in Denmark, Iceland and Norway, TemaNord I, Oslo.

Asche, F., Bjørndal, T. and Gordon, D.V. (2005): Demand Structure for Fish, SNF Working Paper.

Bailey, M., Sumaila, U.R. and Lindroos, M. (2010): Applications of Game Theory to Fisheries over Three Decades, Fisheries Research, 102, pp. 1-8.

Cheung, W.W.L,, Pinnegar, J., Merino, G. and Barange, M. (2012): Impacts of Marine Climate Change on Fisheries in the EK and Ireland, Aquaculture Conservation of Marine Freshwater Ecosystems, 22, pp. 368-388.

Clark, C.W. (1990): Mathematical Bioeconomics: The Optimal Management of Renewable Resources, John Wiley and Sons, New York.

Conrad, J.M. and Clark, C.W. (1991): Natural Resource Economics. Notes and Problems, Cambridge University Press, Cambridge.

Ellefsen, H. (2013). The Stability of Fishing Agreements with Entry: The Northeast Atlantic Mackerel, Strategic Behavior and the Environment, 3, pp. 67-95.

Friedman, J.W. (1979): Game Theory with Applications to Economics, Oxford University Press, Oxford. 
Hannesson, R. (2012): Sharing a Migrating Fish Stock, Marine Resource Economics, 28, pp. 117.

Hannesson, R. (2011): Game Theory and Fisheries, Annual Review of Resource Economics, 3, pp. 181-202.

Holden, M. (1996): The Common Fisheries Policy: Origin, Evaluation and Future, Fishing New Books, Oxford.

Gronbæk, L. and Lindroos, M. (2007): Sharing Rules and Stability in Coalition Games with Externalities, Marine Resource Economics, 22, pp. 33-45.

ICES (2017): Advice, 2017. Book 9, ICES, Copenhagen.

ICES (2010): Advice, 2017. Book 9, ICES, Copenhagen.

Jensen, F., Nielsen, M., Ellefsen, H. and Vestergaard, N. (2018): Economic Welfare in Fisheries: Examples of Inconsistent Definitions, Submitted to Fisheries Research.

Jensen, F., Frost, H., Thogersen, T.T., Andersen, P. and Andersen, J.L. (2015): Game Theory and Fish Wars: The Case of the Northeast Atlantic Mackerel Fishery, Fisheries Research, 172, pp. 716.

Jensen, F. and Vestergaard, N. (2002): Moral Hazard Problems in Fisheries: The Case of Illegal Landings and Discard, Resource and Energy Economics, 24, pp. 281-299.

Johnston, J. (1984): Econometric Methods, McGraw-Hill, Singapore.

Kennedy, J. (2003): Scope for Efficient Multinational Exploitation of the North-East Atlantic Mackerel, Marine Resource Economics, 18, pp. 55-80.

Miller, K.A., Munro, G.R., Sumaila, U.R. and Cheung; W.W,L (2013): Governing Marine Fisheries in a Changing Climate: A Game Theoretical Perspective, Canadian Journal of Agricultural Science, 61, pp. 309-334.

Neher, P. (1990): Natural Resource Economics, Cambridge University Press, Cambridge,.

Pham Do, K. and Folmer, H. (2006): International Fisheries Agreements: The Feasibility and Impacts of Partial Cooperation in Aronsson, T., Axelsson, R. and Brainlund; G. (ed): The Theory and Practise of Environmental and Resource Economics, Edgar Elgar, Cheltenham.

Pintassilgo, P (2003): A Coalition Approach to the Management of High Seas Fisheries in the Presence of Externalities, Natural Resource Modelling, 16, pp. 175-197. 
Pintassilgo, P. and Lindroos, M. (2009): Coalition Formation in Straddling Stock Fisheries: A Partition Function Approach, International Game Theory Review, 25, pp. 33-44.

Pintassilgo, P., Finus, M., Lindroos, M. and Gordon, D. (2008): Stability and Success of Regional Fisheries Management, Working Paper, University of Rome.

Skonhoft, A. and Gong, P. (2016): Maximum Sustainable Yield Harvesting in an Age-Structured Fisheries Population Model, Natural Resource Modelling, 25, pp. 610-632.

Squires, D., Herrick, S.F., and Hastie, J. (1989): Integration of Japanese and United States Sablefish Markets, Fishery Bulletin, 87, pp. 511-527.

Sumaila, U.R. (1997): Strategic Dynamic Interaction: The Case of the Barents Sea Fisheries, Marine Resource Economics, 12, pp. 77-94.

Tahvonen, O., Quass, M.F. and Voss, R. (2018): Harvesting Selectivity and Stochastic Recruitment in Economic Models of Age-Structured Fisheries, Journal of Environmental Economics and Management (forthcoming).

The Norwegian Government (2014): Agreed Record on a Fisheries Arrangement between the European Union, the Faroe Islands and Norway on the Management of Mackerel in the NorthEast Atlantic from 2014 to 2018, Oslo.

The Icelandic Ministry of Fisheries (2009): News and Publications, Reykjavik.

The Norwegian Ministry of Fisheries (2010a): Bilateral Agreement on the Management of Mackerel between the European Union and Norway, Oslo.

The Norwegian Ministry of Fisheries (2010b): Norwegian Ban of Landings of Mackerel against Faroese and Icelandic Vessels, Oslo.

Tveteras, S., Asche, F., Bellemare, W.F., Smith, M.D., Guttermson, A.G., Len, A., Lien, K. and Vannuccini, S. (2014): Fish is Food - The FAO's Fish Price Index, PlosOne, 7, pp. 1-6. 
Table 8: Sensitivity analysis for the parameters in the cost functions for three-player coalitions.

\begin{tabular}{|c|c|c|c|c|}
\hline Grand coalition & Benchmark case & $\begin{array}{l}\text { Case 11: }\{\mathrm{EU}, \mathrm{NO}, \mathrm{IC}\} \\
\text { decrease }\end{array}$ & $\begin{array}{l}\text { Case 12: }\{\mathrm{EU}, \mathrm{NO}, \mathrm{IC}\} \\
\text { increase }\end{array}$ & $\begin{array}{l}\text { Case 13: }\{\mathrm{EU}, \mathrm{NO}, \mathrm{FI}\} \\
\text { decrease }\end{array}$ \\
\hline$[\{\mathrm{EU}, \mathrm{NO}, \mathrm{IC}, \mathrm{FI}\}]$ & $\{784\}$ & $\{784\}$ & $\{784\}$ & $\{784\}$ \\
\hline \multicolumn{5}{|c|}{$\begin{array}{l}\text { Three-player against one- } \\
\text { player }\end{array}$} \\
\hline$[\{\mathrm{EU}, \mathrm{NO}, \mathrm{IC}\} ;\{\mathrm{FI}\}]$ & $\{548\},\{259\}$ & $\{637\},\{251\}$ & $\{481\},\{265\}$ & $\{548\},\{259\}$ \\
\hline$[\{\mathrm{EU}, \mathrm{NO}, \mathrm{FI}\} ;\{\mathrm{IC})]$ & $\{491\},\{275\}$ & $\{491\},\{275\}$ & $\{491\},\{275\}$ & $\{585\},\{266\}$ \\
\hline$[\{\mathrm{EU}, \mathrm{IC}, \mathrm{FI}\} ;\{\mathrm{NO}\}]$ & $\{653\},\{100\}$ & $\{653\},\{100\}$ & $\{653\},\{100\}$ & $\{653\},\{100\}$ \\
\hline$[\{\mathrm{NO}, \mathrm{IC}, \mathrm{FI}\} ;\{\mathrm{EU}\}]$ & $\{622\},\{242\}$ & $\{622\},\{242\}$ & $\{622\},\{242\}$ & $\{622\},\{242\}$ \\
\hline \multicolumn{5}{|c|}{$\begin{array}{l}\text { Two-player against two- } \\
\text { player }\end{array}$} \\
\hline$[\{\mathrm{EU}, \mathrm{NO}\} ;\{\mathrm{IC}, \mathrm{FI}\}]$ & $\{298\},\{590\}$ & $\{298\},\{590\}$ & $\{298\},\{590\}$ & $\{298\},\{590\}$ \\
\hline$[\{\mathrm{EU}, \mathrm{IC}\} ;\{\mathrm{NO}, \mathrm{FI}\}]$ & $\{504\},\{316\}$ & $\{504\},\{316\}$ & $\{504\},\{316\}$ & $\{504\},\{316\}$ \\
\hline$[\{\mathrm{EU}, \mathrm{FI}\} ;\{\mathrm{NO}, \mathrm{IC}\}]$ & $\{359\},\{339\}$ & $\{359\},\{339\}$ & $\{359\},\{339\}$ & $\{359\},\{339\}$ \\
\hline \multicolumn{5}{|c|}{$\begin{array}{l}\text { Two-player against one- } \\
\text { player }\end{array}$} \\
\hline$[\{\mathrm{EU}, \mathrm{NO}\} ;\{\mathrm{IC}\} ;\{\mathrm{FI}\}]$ & $\{303\},\{266\},\{254\}$ & $\{303\},\{266\},\{254\}$ & $\{303\},\{266\},\{254\}$ & $\{303\},\{266\},\{254\}$ \\
\hline$[\{\mathrm{EU}, \mathrm{IC}\} ;\{\mathrm{NO}\} ;\{\mathrm{FI}\}]$ & $\{496\},\{96\},\{253\}$ & $\{496\},\{96\},\{253\}$ & $\{496\},\{96\},\{253\}$ & $\{496\},\{96\},\{253\}$ \\
\hline$[\{\mathrm{EU}, \mathrm{FI}\} ;\{\mathrm{NO}\} ;\{\mathrm{IC}\}]$ & $\{353\},\{100\},\{277\}$ & $\{353\},\{100\},\{277\}$ & $\{353\},\{100\},\{277\}$ & $\{353\},\{100\},\{277\}$ \\
\hline$[\{\mathrm{NO}, \mathrm{IC}\} ;\{\mathrm{EU}\} ;\{\mathrm{FI}\}]$ & $\{320\},\{243\},\{255\}$ & $\{320\},\{243\},\{255\}$ & $\{320\},\{243\},\{255\}$ & $\{320\},\{243\},\{255\}$ \\
\hline$[\{\mathrm{NO}, \mathrm{FI}\} ;\{\mathrm{EU}\} ;\{\mathrm{IC}\}]$ & $\{313\},\{243\},\{266\}$ & $\{313\},\{243\},\{266\}$ & $\{313\},\{243\},\{266\}$ & $\{313\},\{243\},\{266\}$ \\
\hline$[\{\mathrm{IC}, \mathrm{FI}\} ;\{\mathrm{EU}\} ;(\mathrm{NO}\}]$ & $\{582\},\{236\},\{93\}$ & $\{582\},\{236\},\{93\}$ & $\{582\},\{236\},\{93\}$ & $\{582\},\{236\},\{93\}$ \\
\hline \multicolumn{5}{|l|}{ Standing-alone } \\
\hline$[\{\mathrm{EU}\} ;\{\mathrm{NO}\} ;\{\mathrm{IC}\} ;\{\mathrm{FI}\}]$ & $\{239\},\{95\},\{263\},\{250\}$ & $\{239\},\{95\},\{263\},\{250\}$ & $\{239\},\{95\},\{263\},\{250\}$ & $\{239\},\{95\},\{263\},\{250\}$ \\
\hline \multicolumn{5}{|c|}{ Internally stable coalitions } \\
\hline Coalition structures & {$[\{\mathrm{IC}, \mathrm{FI}\} ;\{\mathrm{EU}\} ;(\mathrm{NO}\}]$} & $\begin{array}{l}{[\{\mathrm{IC}, \mathrm{FI}\} ;\{\mathrm{EU}\} ;(\mathrm{NO}\}],} \\
{[\{\mathrm{EU}, \mathrm{NO}, \mathrm{IC}\},\{\mathrm{FI}\}]}\end{array}$ & {$[\{\mathrm{IC}, \mathrm{FI}\} ;\{\mathrm{EU}\} ;(\mathrm{NO}\}]$} & $\begin{array}{l}{[\{\mathrm{IC}, \mathrm{FI}\} ;\{\mathrm{EU}\} ;(\mathrm{NO}\}]} \\
{[\{\mathrm{EU}, \mathrm{NO}, \mathrm{FI}\},\{\mathrm{IC}\}]}\end{array}$ \\
\hline
\end{tabular}


Table 8 (continued).

\begin{tabular}{|c|c|c|c|c|}
\hline Grand coalition & Benchmark case & $\begin{array}{l}\text { Case 14: }\{\mathrm{EU}, \mathrm{NO}, \mathrm{FI}\} \\
\text { increase }\end{array}$ & $\begin{array}{l}\text { Case 15: }\{\mathrm{EU}, \mathrm{IC}, \mathrm{FI}\} \\
\text { decrease }\end{array}$ & $\begin{array}{l}\text { Case 16: }\{\mathrm{EU}, \mathrm{IC}, \mathrm{FI}\} \\
\text { increase }\end{array}$ \\
\hline$[\{\mathrm{EU}, \mathrm{NO}, \mathrm{IC}, \mathrm{FI}\}]$ & $\{784\}$ & $\{784\}$ & $\{784\}$ & $\{784\}$ \\
\hline \multicolumn{5}{|c|}{$\begin{array}{l}\text { Three-player against one- } \\
\text { player }\end{array}$} \\
\hline$[\{\mathrm{EU}, \mathrm{NO}, \mathrm{IC}\} ;\{\mathrm{FI}\}]$ & $\{548\},\{259\}$ & $\{548\},\{259\}$ & $\{548\},\{259\}$ & $\{548\},\{259\}$ \\
\hline$[\{\mathrm{EU}, \mathrm{NO}, \mathrm{FI}\} ;\{\mathrm{IC})]$ & $\{491\},\{275\}$ & $\{422\},\{282\}$ & $\{491\},\{275\}$ & $\{491\},\{272\}$ \\
\hline$[\{\mathrm{EU}, \mathrm{IC}, \mathrm{FI}\} ;\{\mathrm{NO}\}]$ & $\{653\},\{100\}$ & $\{653\},\{100\}$ & $\{761\},\{97\}$ & $\{572\},\{103\}$ \\
\hline$[\{\mathrm{NO}, \mathrm{IC}, \mathrm{FI}\} ;\{\mathrm{EU}\}]$ & $\{622\},\{242\}$ & $\{622\},\{242\}$ & $\{622\},\{242\}$ & $\{622\},\{242\}$ \\
\hline \multicolumn{5}{|c|}{$\begin{array}{l}\text { Two-player against two- } \\
\text { player }\end{array}$} \\
\hline$[\{\mathrm{EU}, \mathrm{NO}\} ;\{\mathrm{IC}, \mathrm{FI}\}]$ & $\{298\},\{590\}$ & $\{298\},\{590\}$ & $\{298\},\{590\}$ & $\{298\},\{590\}$ \\
\hline$[\{\mathrm{EU}, \mathrm{IC}\} ;\{\mathrm{NO}, \mathrm{FI}\}]$ & $\{504\},\{316\}$ & $\{504\},\{316\}$ & $\{504\},\{316\}$ & $\{504\},\{316\}$ \\
\hline$[\{\mathrm{EU}, \mathrm{FI}\} ;\{\mathrm{NO}, \mathrm{IC}\}]$ & $\{359\},\{339\}$ & $\{359\},\{339\}$ & $\{359\},\{339\}$ & $\{359\},\{339\}$ \\
\hline \multicolumn{5}{|c|}{$\begin{array}{l}\text { Two-player against one- } \\
\text { player }\end{array}$} \\
\hline$[\{\mathrm{EU}, \mathrm{NO}\} ;\{\mathrm{IC}\} ;\{\mathrm{FI}\}]$ & $\{303\},\{266\},\{254\}$ & $\{303\},\{266\},\{254\}$ & $\{303\},\{266\},\{254\}$ & $\{303\},\{266\},\{254\}$ \\
\hline$[\{\mathrm{EU}, \mathrm{IC}\} ;\{\mathrm{NO}\} ;\{\mathrm{FI}\}]$ & $\{496\},\{96\},\{253\}$ & $\{496\},\{96\},\{253\}$ & $\{496\},\{96\},\{253\}$ & $\{496\},\{96\},\{253\}$ \\
\hline$[\{\mathrm{EU}, \mathrm{FI}\} ;\{\mathrm{NO}\} ;\{\mathrm{IC}\}]$ & $\{353\},\{100\},\{277\}$ & $\{353\},\{100\},\{277\}$ & $\{353\},\{100\},\{277\}$ & $\{353\},\{100\},\{277\}$ \\
\hline$[\{\mathrm{NO}, \mathrm{IC}\} ;\{\mathrm{EU}\} ;\{\mathrm{FI}\}]$ & $\{320\},\{243\},\{255\}$ & $\{320\},\{243\},\{255\}$ & $\{320\},\{243\},\{255\}$ & $\{320\},\{243\},\{255\}$ \\
\hline$[\{\mathrm{NO}, \mathrm{FI}\} ;\{\mathrm{EU}\} ;\{\mathrm{IC}\}]$ & $\{313\},\{243\},\{266\}$ & $\{313\},\{243\},\{266\}$ & $\{313\},\{243\},\{266\}$ & $\{313\},\{243\},\{266\}$ \\
\hline$[\{\mathrm{IC}, \mathrm{FI}\} ;\{\mathrm{EU}\} ;(\mathrm{NO}\}]$ & $\{582\},\{236\},\{93\}$ & $\{582\},\{236\},\{93\}$ & $\{582\},\{236\},\{93\}$ & $\{582\},\{236\},\{93\}$ \\
\hline \multicolumn{5}{|l|}{ Standing-alone } \\
\hline$[\{\mathrm{EU}\} ;\{\mathrm{NO}\} ;\{\mathrm{IC}\} ;\{\mathrm{FI}\}]$ & $\{239\},\{95\},\{263\},\{250\}$ & $\{239\},\{95\},\{263\},\{250\}$ & $\{239\},\{95\},\{263\},\{250\}$ & $\{239\},\{95\},\{263\},\{250\}$ \\
\hline \multicolumn{5}{|c|}{ Internally stable coalitions } \\
\hline Coalition structures & {$[\{\mathrm{IC}, \mathrm{FI}\} ;\{\mathrm{EU}\} ;(\mathrm{NO}\}]$} & {$[\{\mathrm{IC}, \mathrm{FI}\} ;\{\mathrm{EU}\} ;(\mathrm{NO}\}]$} & $[\{\mathrm{IC}, \mathrm{FI}\} ;\{\mathrm{EU}\} ; \mathrm{NO}\}]$ & {$[\{\mathrm{IC}, \mathrm{FI}\} ;\{\mathrm{EU}\} ;(\mathrm{NO}\}]$} \\
\hline
\end{tabular}


Table 8 (continued).

\begin{tabular}{|c|c|c|c|}
\hline Grand coalition & Benchmark case & Case 17: $\{\mathrm{NO}, \mathrm{IC}, \mathrm{FI}\}$ decrease & Case 18: $\{\mathrm{NO}, \mathrm{IC}, \mathrm{FI}\}$ increase \\
\hline$[\{\mathrm{EU}, \mathrm{NO}, \mathrm{IC}, \mathrm{FI}\}]$ & $\{784\}$ & $\{784\}$ & $\{784\}$ \\
\hline \multicolumn{4}{|c|}{$\begin{array}{l}\text { Three-player against one- } \\
\text { player }\end{array}$} \\
\hline$[\{\mathrm{EU}, \mathrm{NO}, \mathrm{IC}\} ;\{\mathrm{FI}\}]$ & $\{548\},\{259\}$ & $\{548\},\{259\}$ & $\{548\},\{259\}$ \\
\hline$[\{\mathrm{EU}, \mathrm{NO}, \mathrm{FI}\} ;\{\mathrm{IC})]$ & $\{491\},\{275\}$ & $\{491\},\{275\}$ & $\{491\},\{275\}$ \\
\hline$[\{\mathrm{EU}, \mathrm{IC}, \mathrm{FI}\} ;\{\mathrm{NO}\}]$ & $\{653\},\{100\}$ & $\{653\},\{100\}$ & $\{653\},\{100\}$ \\
\hline$[\{\mathrm{NO}, \mathrm{IC}, \mathrm{FI}\} ;\{\mathrm{EU}\}]$ & $\{622\},\{242\}$ & $\{738\},\{232\}$ & $\{537\},\{249\}$ \\
\hline \multicolumn{4}{|c|}{$\begin{array}{l}\text { Two-player against two- } \\
\text { player }\end{array}$} \\
\hline$[\{\mathrm{EU}, \mathrm{NO}\} ;\{\mathrm{IC}, \mathrm{FI}\}]$ & $\{298\},\{590\}$ & $\{298\},\{590\}$ & $\{298\},\{590\}$ \\
\hline$[\{\mathrm{EU}, \mathrm{IC}\} ;\{\mathrm{NO}, \mathrm{FI}\}]$ & $\{504\},\{316\}$ & $\{504\},\{316\}$ & $\{504\},\{316\}$ \\
\hline$[\{\mathrm{EU}, \mathrm{FI}\} ;\{\mathrm{NO}, \mathrm{IC}\}]$ & $\{359\},\{339\}$ & $\{359\},\{339\}$ & $\{359\},\{339\}$ \\
\hline \multicolumn{4}{|c|}{$\begin{array}{l}\text { Two-player against one- } \\
\text { player }\end{array}$} \\
\hline$[\{\mathrm{EU}, \mathrm{NO}\} ;\{\mathrm{IC}\} ;\{\mathrm{FI}\}]$ & $\{303\},\{266\},\{254\}$ & $\{303\},\{266\},\{254\}$ & $\{303\},\{266\},\{254\}$ \\
\hline$[\{\mathrm{EU}, \mathrm{IC}\} ;\{\mathrm{NO}\} ;\{\mathrm{FI}\}]$ & $\{496\},\{96\},\{253\}$ & $\{496\},\{96\},\{253\}$ & $\{496\},\{96\},\{253\}$ \\
\hline$[\{\mathrm{EU}, \mathrm{FI}\} ;\{\mathrm{NO}\} ;\{\mathrm{IC}\}]$ & $\{353\},\{100\},\{277\}$ & $\{353\},\{100\},\{277\}$ & $\{353\},\{100\},\{277\}$ \\
\hline$[\{\mathrm{NO}, \mathrm{IC}\} ;\{\mathrm{EU}\} ;\{\mathrm{FI}\}]$ & $\{320\},\{243\},\{255\}$ & $\{320\},\{243\},\{255\}$ & $\{320\},\{243\},\{255\}$ \\
\hline$[\{\mathrm{NO}, \mathrm{FI}\} ;\{\mathrm{EU}\} ;\{\mathrm{IC}\}]$ & $\{313\},\{243\},\{266\}$ & $\{313\},\{243\},\{266\}$ & $\{313\},\{243\},\{266\}$ \\
\hline$[\{\mathrm{IC}, \mathrm{FI}\} ;\{\mathrm{EU}\} ;(\mathrm{NO}\}]$ & $\{582\},\{236\},\{93\}$ & $\{582\},\{236\},\{93\}$ & $\{582\},\{236\},\{93\}$ \\
\hline \multicolumn{4}{|l|}{ Standing-alone } \\
\hline$[\{\mathrm{EU}\} ;\{\mathrm{NO}\} ;\{\mathrm{IC}\} ;\{\mathrm{FI}\}]$ & $\{239\},\{95\},\{263\},\{250\}$ & $\{239\},\{95\},\{263\}, 250\}$ & $\{239\},\{95\},\{263\},\{250\}$ \\
\hline \multicolumn{4}{|c|}{ Internally stable coalitions } \\
\hline Coalition structures & {$[\{\mathrm{IC}, \mathrm{FI}\} ;\{\mathrm{EU}\} ;(\mathrm{NO}\}]$} & $\begin{array}{l}{[\{\mathrm{IC}, \mathrm{FI}\} ;\{\mathrm{EU}\} ;(\mathrm{NO}\}]} \\
{[\{\mathrm{NO}, \mathrm{IC}, \mathrm{FI}\} ;\{\mathrm{EU}\}]}\end{array}$ & {$[\{\mathrm{IC}, \mathrm{FI}\} ;\{\mathrm{EU}\} ;(\mathrm{NO}\}]$} \\
\hline
\end{tabular}

Note: In the table we omit the trivial internally stable coalition structure where all players stand-alone (the singleton). 
Table 9: Sensitivity analysis for the parameters in the cost functions for two-player coalitions.

\begin{tabular}{|c|c|c|c|c|}
\hline Grand coalition & Benchmark case & $\begin{array}{l}\text { Case 19: }\{\mathrm{EU}, \mathrm{NO}\} \\
\text { decrease }\end{array}$ & $\begin{array}{l}\text { Case 20: }\{\mathrm{EU}, \mathrm{NO}\} \\
\text { increase }\end{array}$ & $\begin{array}{l}\text { Case 21: }\{\mathrm{EU}, \mathrm{IC}\} \\
\text { decrease }\end{array}$ \\
\hline$[\{\mathrm{EU}, \mathrm{NO}, \mathrm{IC}, \mathrm{FI}\}]$ & $\{784\}$ & $\{784\}$ & $\{784\}$ & $\{784\}$ \\
\hline \multicolumn{5}{|c|}{$\begin{array}{l}\text { Three-player against one- } \\
\text { player }\end{array}$} \\
\hline$[\{\mathrm{EU}, \mathrm{NO}, \mathrm{IC}\} ;\{\mathrm{FI}\}]$ & $\{548\},\{259\}$ & $\{548\},\{259\}$ & $\{548\},\{259\}$ & $\{548\},\{259\}$ \\
\hline$[\{\mathrm{EU}, \mathrm{NO}, \mathrm{FI}\} ;\{\mathrm{IC})]$ & $\{491\},\{275\}$ & $\{491\},\{275\}$ & $\{491\},\{275\}$ & $\{491\},\{275\}$ \\
\hline$[\{\mathrm{EU}, \mathrm{IC}, \mathrm{FI}\} ;\{\mathrm{NO}\}]$ & $\{653\},\{100\}$ & $\{653\},\{100\}$ & $\{653\}\{100\}$ & $\{653\},\{100\}$ \\
\hline$[\{\mathrm{NO}, \mathrm{IC}, \mathrm{FI}\} ;\{\mathrm{EU}\}]$ & $\{622\},\{242\}$ & $\{622\},\{242\}$ & $\{622\},\{242\}$ & $\{622\},\{242\}$ \\
\hline \multicolumn{5}{|c|}{$\begin{array}{l}\text { Two-player against two- } \\
\text { player }\end{array}$} \\
\hline$[\{\mathrm{EU}, \mathrm{NO}\} ;\{\mathrm{IC}, \mathrm{FI}\}]$ & $\{298\},\{590\}$ & $\{347\},\{580\}$ & $\{261\},\{597\}$ & $\{298\},\{590\}$ \\
\hline$[\{\mathrm{EU}, \mathrm{IC}\} ;\{\mathrm{NO}, \mathrm{FI}\}]$ & $\{504\},\{316\}$ & $\{504\},\{316\}$ & $\{504\},\{316\}$ & $\{556\},\{310\}$ \\
\hline$[\{\mathrm{EU}, \mathrm{FI}\} ;\{\mathrm{NO}, \mathrm{IC}\}]$ & $\{359\},\{339\}$ & $\{359\},\{339\}$ & $\{359\},\{339\}$ & $\{359\},\{339\}$ \\
\hline \multicolumn{5}{|c|}{$\begin{array}{l}\text { Two-player against one- } \\
\text { player }\end{array}$} \\
\hline$[\{\mathrm{EU}, \mathrm{NO}\} ;\{\mathrm{IC}\} ;\{\mathrm{FI}\}]$ & $\{303\},\{266\},\{254\}$ & $\{353\},\{262\},\{250\}$ & $\{265\},\{270\},\{257\}$ & $\{303\},\{266\},\{254\}$ \\
\hline$[\{\mathrm{EU}, \mathrm{IC}\} ;\{\mathrm{NO}\} ;\{\mathrm{FI}\}]$ & $\{496\},\{96\},\{253\}$ & $\{496\},\{96\},\{253\}$ & $\{496\},\{96\},\{253\}$ & $\{548\},\{94\},\{249\}$ \\
\hline$[\{\mathrm{EU}, \mathrm{FI}\} ;\{\mathrm{NO}\} ;\{\mathrm{IC}\}]$ & $\{353\},\{100\},\{277\}$ & $\{353\},\{100\},\{277\}$ & $\{353\}, 100\},\{277\}$ & $\{353\}, 100\},\{277\}$ \\
\hline$[\{\mathrm{NO}, \mathrm{IC}\} ;\{\mathrm{EU}\} ;\{\mathrm{FI}\}]$ & $\{320\},\{243\},\{255\}$ & $\{320\},\{243\},\{255\}$ & $\{320\},\{243\},\{255\}$ & $\{320\},\{243\},\{255\}$ \\
\hline$[\{\mathrm{NO}, \mathrm{FI}\} ;\{\mathrm{EU}\} ;\{\mathrm{IC}\}]$ & $\{313\},\{243\},\{266\}$ & $\{313\},\{243\},\{266\}$ & $\{313\},\{243\},\{266\}$ & $\{313\},\{243\},\{266\}$ \\
\hline$[\{\mathrm{IC}, \mathrm{FI}\} ;\{\mathrm{EU}\} ;(\mathrm{NO}\}]$ & $\{582\},\{236\},\{93\}$ & $\{582\},\{236\},\{93\}$ & $\{582\},\{236\},\{93\}$ & $\{582\},\{236\},\{93\}$ \\
\hline \multicolumn{5}{|l|}{ Standing-alone } \\
\hline$[\{\mathrm{EU}\} ;\{\mathrm{NO}\} ;\{\mathrm{IC}\} ;\{\mathrm{FI}\}]$ & $\{239\},\{95\},\{263\},\{250\}$ & $\{239\},\{95\},\{263\},\{250\}$ & $\{239\},\{95\}, 263\},\{250\}$ & $\{239\},\{95\},\{263\},\{250\}$ \\
\hline \multicolumn{5}{|c|}{ Internally stable coalitions } \\
\hline Coalition structures & {$[\{\mathrm{IC}, \mathrm{FI}\} ;\{\mathrm{EU}\} ;(\mathrm{NO}\}]$} & $\begin{array}{l}{[\{\mathrm{IC}, \mathrm{FI}\} ;\{\mathrm{EU}\} ;\{\mathrm{NO}\}]} \\
{[\{\mathrm{EU}, \mathrm{NO}\} ;\{\mathrm{IC}, \mathrm{FI}\}]} \\
{[\{\mathrm{EU}, \mathrm{NO}\} ;\{\mathrm{IC}\},\{\mathrm{FI}\}]}\end{array}$ & {$[\{\mathrm{IC}, \mathrm{FI}\} ;\{\mathrm{EU}\} ;(\mathrm{NO}\}]$} & $\begin{array}{l}{[\{\mathrm{IC}, \mathrm{FI}\} ;\{\mathrm{EU}\} ;(\mathrm{NO}\}],} \\
{[\{\mathrm{EU}, \mathrm{IC}\} ;\{\mathrm{NO}\},\{\mathrm{FI}\}]}\end{array}$ \\
\hline
\end{tabular}


Table 9 (continued).

\begin{tabular}{|c|c|c|c|c|}
\hline Grand coalition & Benchmark case & $\begin{array}{l}\text { Case 22: }\{\mathrm{EU}, \mathrm{IC}\} \\
\text { increase }\end{array}$ & $\begin{array}{l}\text { Case 23: }\{\mathbf{E U}, \mathbf{F I}\} \\
\text { decrease }\end{array}$ & $\begin{array}{l}\text { Case 24: }\{\mathbf{E U}, \mathbf{F I}\} \\
\text { increase }\end{array}$ \\
\hline \multicolumn{5}{|c|}{$\begin{array}{l}\text { Three-player against one- } \\
\text { player }\end{array}$} \\
\hline$[\{\mathrm{EU}, \mathrm{NO}, \mathrm{IC}\} ;\{\mathrm{FI}\}]$ & $\{548\},\{259\}$ & $\{548\},\{259\}$ & $\{548\},\{259\}$ & $\{548\},\{259\}$ \\
\hline$[\{\mathrm{EU}, \mathrm{NO}, \mathrm{FI}\} ;\{\mathrm{IC})]$ & $\{491\},\{275\}$ & $\{491\},\{275\}$ & $\{491\},\{275\}$ & $\{491\},\{275\}$ \\
\hline$[\{\mathrm{EU}, \mathrm{IC}, \mathrm{FI}\} ;\{\mathrm{NO}\}]$ & $\{653\},\{100\}$ & $\{653\},\{100\}$ & $\{653\},\{100\}$ & $\{653\},\{100\}$ \\
\hline$[\{\mathrm{NO}, \mathrm{IC}, \mathrm{FI}\} ;\{\mathrm{EU}\}]$ & $\{622\},\{242\}$ & $\{622\},\{242\}$ & $\{622\},\{242\}$ & $\{622\},\{242\}$ \\
\hline \multicolumn{5}{|c|}{$\begin{array}{l}\text { Two-player against two- } \\
\text { player }\end{array}$} \\
\hline$[\{\mathrm{EU}, \mathrm{NO}\} ;\{\mathrm{IC}, \mathrm{FI}\}]$ & $\{298\},\{590\}$ & $\{298\},\{590\}$ & $\{298\},\{590\}$ & $\{298\},\{590\}$ \\
\hline$[\{\mathrm{EU}, \mathrm{IC}\} ;\{\mathrm{NO}, \mathrm{FI}\}]$ & $\{504\},\{316\}$ & $\{460\},\{321\}$ & $\{504\},\{316\}$ & $\{504\},\{316\}$ \\
\hline$[\{\mathrm{EU}, \mathrm{FI}\} ;\{\mathrm{NO}, \mathrm{IC}\}]$ & $\{359\},\{339\}$ & $\{359\},\{339\}$ & $\{398\},\{334\}$ & $\{327\},\{542\}$ \\
\hline \multicolumn{5}{|c|}{$\begin{array}{l}\text { Two-player against one- } \\
\text { player }\end{array}$} \\
\hline$[\{\mathrm{IC}, \mathrm{FI}\} ;\{\mathrm{EU}\} ;(\mathrm{NO}\}]$ & $\{582\},\{236\},\{93\}$ & $\{582\},\{236\},\{93\}$ & $\{582\},\{236\},\{93\}$ & $\{582\},\{236\},\{93\}$ \\
\hline \multicolumn{5}{|l|}{ Standing-alone } \\
\hline$[\{\mathrm{EU}\} ;\{\mathrm{NO}\} ;\{\mathrm{IC}\} ;\{\mathrm{FI}\}]$ & $\{239\},\{95\},\{263\},\{250\}$ & $\{239\},\{95\},\{263\},\{250\}$ & $\{239\},\{95\},\{263\}, 250\}$ & $\{239\},\{95\},\{263\},\{250\}$ \\
\hline \multicolumn{5}{|c|}{ Internally stable coalitions } \\
\hline Coalition structures & {$[\{\mathrm{IC}, \mathrm{FI}\} ;\{\mathrm{EU}\} ;(\mathrm{NO}\}]$} & {$[\{\mathrm{IC}, \mathrm{FI}\} ;\{\mathrm{EU}\} ;(\mathrm{NO}\}]$} & {$[\{\mathrm{IC}, \mathrm{FI}\} ;\{\mathrm{EU}\} ;(\mathrm{NO}\}]$} & {$[\{\mathrm{IC}, \mathrm{FI}\} ;\{\mathrm{EU}\} ;(\mathrm{NO}\}]$} \\
\hline
\end{tabular}


Table 9 (continued).

\begin{tabular}{|c|c|c|c|c|}
\hline Grand coalition & Benchmark case & $\begin{array}{l}\text { Case 25: }\{\text { NO IC }\} \\
\text { decrease }\end{array}$ & $\begin{array}{l}\text { Case 26: }\{\mathrm{NO}, \mathrm{IC}\} \\
\text { increase }\end{array}$ & $\begin{array}{l}\text { Case 27: }\{\mathrm{NO}, \mathrm{FI}\} \\
\text { decrease }\end{array}$ \\
\hline$[\{\mathrm{EU}, \mathrm{NO}, \mathrm{IC}, \mathrm{FI}\}]$ & $\{784\}$ & $\{784\}$ & $\{784\}$ & $\{784\}$ \\
\hline \multicolumn{5}{|c|}{$\begin{array}{l}\text { Three-player against one- } \\
\text { player }\end{array}$} \\
\hline$[\{\mathrm{EU}, \mathrm{NO}, \mathrm{IC}\} ;\{\mathrm{FI}\}]$ & $\{548\},\{259\}$ & $\{548\},\{259\}$ & $\{548\},\{259\}$ & $\{548\},\{259\}$ \\
\hline$[\{\mathrm{EU}, \mathrm{NO}, \mathrm{FI}\} ;\{\mathrm{IC})]$ & $\{491\},\{275\}$ & $\{491\},\{275\}$ & $\{491\},\{275\}$ & $\{491\},\{275\}$ \\
\hline$[\{\mathrm{EU}, \mathrm{IC}, \mathrm{FI}\} ;\{\mathrm{NO}\}]$ & $\{653\},\{100\}$ & $\{653\},\{100\}$ & $\{653\},\{100\}$ & $\{653\},\{100\}$ \\
\hline$[\{\mathrm{NO}, \mathrm{IC}, \mathrm{FI}\} ;\{\mathrm{EU}\}]$ & $\{622\},\{242\}$ & $\{622\},\{242\}$ & $\{622\},\{242\}$ & $\{622\},\{242\}$ \\
\hline \multicolumn{5}{|c|}{$\begin{array}{l}\text { Two-player against two- } \\
\text { player }\end{array}$} \\
\hline$[\{\mathrm{EU}, \mathrm{NO}\} ;\{\mathrm{IC}, \mathrm{FI}\}]$ & $\{298\},\{590\}$ & $\{298\},\{590\}\}$ & $\{298\},\{590\}$ & $\{298\},\{590\}$ \\
\hline$[\{\mathrm{EU}, \mathrm{IC}\} ;\{\mathrm{NO}, \mathrm{FI}\}]$ & $\{504\},\{316\}$ & $\{504\}\{316\}$ & $\{504\}\{316\}$ & $\{495\}\{367\}$ \\
\hline$[\{\mathrm{EU}, \mathrm{FI}\} ;\{\mathrm{NO}, \mathrm{IC}\}]$ & $\{359\},\{339\}$ & $\{353\},\{390\}$ & $\{364\},\{289\}$ & $\{359\},\{339\}$ \\
\hline \multicolumn{5}{|c|}{$\begin{array}{l}\text { Two-player against one- } \\
\text { player }\end{array}$} \\
\hline$[\{\mathrm{EU}, \mathrm{NO}\} ;\{\mathrm{IC}\} ;\{\mathrm{FI}\}]$ & $\{303\},\{266\},\{254\}$ & $\{303\},\{266\},\{254\}$ & $\{303\},\{266\},\{254\}$ & $\{303\},\{266\},\{254\}$ \\
\hline$[\{\mathrm{EU}, \mathrm{IC}\} ;\{\mathrm{NO}\} ;\{\mathrm{FI}\}]$ & $\{496\},\{96\},\{253\}$ & $\{496\},\{96\},\{253\}$ & $\{496\},\{96\},\{253\}$ & $\{496\},\{96\},\{253\}$ \\
\hline$[\{\mathrm{EU}, \mathrm{FI}\} ;\{\mathrm{NO}\} ;\{\mathrm{IC}\}]$ & $\{353\},\{100\},\{277\}$ & $\{353\}, 100\},\{277\}$ & $\{353\}, 100\},\{277\}$ & $\{353\},\{100\},\{277\}$ \\
\hline$[\{\mathrm{NO}, \mathrm{IC}\} ;\{\mathrm{EU}\} ;\{\mathrm{FI}\}]$ & $\{320\},\{243\},\{255\}$ & $\{369\},\{239\},\{250\}$ & $\{283\},\{247\},\{258\}$ & $\{320\},\{243\},\{255\}$ \\
\hline$[\{\mathrm{NO}, \mathrm{FI}\} ;\{\mathrm{EU}\} ;\{\mathrm{IC}\}]$ & $\{313\},\{243\},\{266\}$ & $\{313\},\{243\},\{266\}$ & $\{313\},\{243\},\{266\}$ & $\{363\},\{239\},\{262\}$ \\
\hline$[\{\mathrm{IC}, \mathrm{FI}\} ;\{\mathrm{EU}\} ;(\mathrm{NO}\}]$ & $\{582\},\{236\},\{93\}$ & $\{582\},\{236\},\{93\}$ & $\{582\},\{236\},\{93\}\}$ & $\{582\},\{236\},\{93\}$ \\
\hline \multicolumn{5}{|l|}{ Standing-alone } \\
\hline$[\{\mathrm{EU}\} ;\{\mathrm{NO}\} ;\{\mathrm{IC}\} ;\{\mathrm{FI}\}]$ & $\{239\},\{95\},\{263\},\{250\}$ & $\{239\},\{95\},\{263\}, 250\}$ & $\{239\},\{95\},\{263\}, 250\}$ & $\{239\},\{95\},\{263\}, 250\}$ \\
\hline \multicolumn{5}{|c|}{ Internally stable coalitions } \\
\hline Coalition structures & {$[\{\mathrm{IC}, \mathrm{FI}\} ;\{\mathrm{EU}\} ;(\mathrm{NO}\}]$} & $\begin{array}{l}{[\{\mathrm{IC}, \mathrm{FI}\} ;\{\mathrm{EU}\} ;(\mathrm{NO}\},]} \\
{[\{\mathrm{NO}, \mathrm{IC}\} ;\{\mathrm{EU}\} ;\{\mathrm{FI}\},}\end{array}$ & {$[\{\mathrm{IC}, \mathrm{FI}\} ;\{\mathrm{EU}\} ;(\mathrm{NO}\}]$} & {$[\{\mathrm{IC}, \mathrm{FI}\} ;\{\mathrm{EU}\} ;(\mathrm{NO}\}]$} \\
\hline
\end{tabular}


Table 9 (continued).

\begin{tabular}{|c|c|c|c|c|}
\hline Grand coalition & Benchmark case & $\begin{array}{l}\text { Case 28: }\{\mathrm{NO}, \mathrm{FI}\} \\
\text { Increase }\end{array}$ & $\begin{array}{l}\text { Case 29: }\{\text { IC,FI }\} \\
\text { decrease }\end{array}$ & $\begin{array}{l}\text { Case 30: }\{\text { IC,FI }\} \\
\text { increase }\end{array}$ \\
\hline$[\{\mathrm{EU}, \mathrm{NO}, \mathrm{IC}, \mathrm{FI}\}]$ & $\{784\}$ & $\{784\}$ & $\{784\}$ & $\{784\}$ \\
\hline \multicolumn{5}{|c|}{$\begin{array}{l}\text { Three-player against one- } \\
\text { player }\end{array}$} \\
\hline$[\{\mathrm{EU}, \mathrm{NO}, \mathrm{IC}\} ;\{\mathrm{FI}\}]$ & $\{548\},\{259\}$ & $\{548\},\{259\}$ & $\{548\},\{259\}$ & $\{548\},\{259\}$ \\
\hline$[\{\mathrm{EU}, \mathrm{NO}, \mathrm{FI}\} ;\{\mathrm{IC})]$ & $\{491\},\{275\}$ & $\{491\},\{275\}$ & $\{491\},\{275\}$ & $\{491\},\{275\}$ \\
\hline$[\{\mathrm{EU}, \mathrm{IC}, \mathrm{FI}\} ;\{\mathrm{NO}\}]$ & $\{653\},\{100\}$ & $\{653\},\{100\}$ & $\{653\},\{100\}$ & $\{653\},\{100\}$ \\
\hline$[\{\mathrm{NO}, \mathrm{IC}, \mathrm{FI}\} ;\{\mathrm{EU}\}]$ & $\{622\},\{242\}$ & $\{622\},\{242\}$ & $\{622\},\{242\}$ & $\{622\},\{242\}$ \\
\hline \multicolumn{5}{|c|}{$\begin{array}{l}\text { Two-player against two- } \\
\text { player }\end{array}$} \\
\hline$[\{\mathrm{EU}, \mathrm{NO}\} ;\{\mathrm{IC}, \mathrm{FI}\}]$ & $\{298\},\{590\}$ & $\{298\},\{590\}$ & $\{298\},\{590\}$ & $\{298\},\{590\}$ \\
\hline$[\{\mathrm{EU}, \mathrm{IC}\} ;\{\mathrm{NO}, \mathrm{FI}\}]$ & $\{504\},\{316\}$ & $\{510\}\{278\}$ & $\{504\},\{316\}$ & $\{504\},\{316\}$ \\
\hline$[\{\mathrm{EU}, \mathrm{FI}\} ;\{\mathrm{NO}, \mathrm{IC}\}]$ & $\{359\},\{339\}$ & $\{359\},\{339\}$ & $\{359\},\{339\}$ & $\{359\},\{339\}$ \\
\hline \multicolumn{5}{|c|}{$\begin{array}{l}\text { Two-player against one- } \\
\text { player }\end{array}$} \\
\hline$[\{\mathrm{EU}, \mathrm{NO}\} ;\{\mathrm{IC}\} ;\{\mathrm{FI}\}]$ & $\{303\},\{266\},\{254\}$ & $\{303\},\{266\},\{254\}$ & $\{303\},\{266\},\{254\}$ & $\{303\},\{266\},\{254\}$ \\
\hline$[\{\mathrm{EU}, \mathrm{IC}\} ;\{\mathrm{NO}\} ;\{\mathrm{FI}\}]$ & $\{496\},\{96\},\{253\}$ & $\{496\},\{96\},\{253\}$ & $\{496\},\{96\},\{253\}$ & $\{496\},\{96\},\{253\}$ \\
\hline$[\{\mathrm{EU}, \mathrm{FI}\} ;\{\mathrm{NO}\} ;\{\mathrm{IC}\}]$ & $\{353\},\{100\},\{277\}$ & $\{353\},\{100\},\{277\}$ & $\{353\},\{100\},\{277\}$ & $\{353\},\{100\},\{277\}$ \\
\hline$[\{\mathrm{NO}, \mathrm{IC}\} ;\{\mathrm{EU}\} ;\{\mathrm{FI}\}]$ & $\{320\},\{243\},\{255\}$ & $\{320\},\{243\},\{255\}$ & $\{320\},\{243\},\{255\}$ & $\{320\},\{243\},\{255\}$ \\
\hline$[\{\mathrm{NO}, \mathrm{FI}\} ;\{\mathrm{EU}\} ;\{\mathrm{IC}\}]$ & $\{313\},\{243\},\{266\}$ & $\{275\},\{246\},\{270\}$ & $\{313\},\{243\},\{266\}$ & $\{313\},\{243\},\{266\}$ \\
\hline$[\{\mathrm{IC}, \mathrm{FI}\} ;\{\mathrm{EU}\} ;(\mathrm{NO}\}]$ & $\{582\},\{236\},\{93\}$ & $\{582\},\{236\},\{93\}$ & $\{658\},\{229\},\{91\}$ & $\{521\},\{241\},\{95\}$ \\
\hline \multicolumn{5}{|l|}{ Standing-alone } \\
\hline$[\{\mathrm{EU}\} ;\{\mathrm{NO}\} ;\{\mathrm{IC}\} ;\{\mathrm{FI}\}]$ & $\{239\},\{95\},\{263\},\{250\}$ & $\{239\},\{95\},\{263\}, 250\}$ & $\{239\},\{95\},\{263\},\{250\}$ & $\{239\},\{95\},\{263\}, 250\}$ \\
\hline \multicolumn{5}{|c|}{ Internally stable coalitions } \\
\hline Coalition structures & {$[\{\mathrm{IC}, \mathrm{FI}\} ;\{\mathrm{EU}\} ;(\mathrm{NO}\}]$} & {$[\{\mathrm{IC}, \mathrm{FI}\} ;\{\mathrm{EU}\} ;(\mathrm{NO}\}]$} & {$[\{\mathrm{IC}, \mathrm{FI}\} ;\{\mathrm{EU}\} ;(\mathrm{NO}\}]$} & $\begin{array}{l}{[\{\mathrm{IC}, \mathrm{FI}\} ;\{\mathrm{EU}\} ;(\mathrm{NO}\}]} \\
{[\{\mathrm{NO}, \mathrm{IC}, \mathrm{FI}\} ;\{\mathrm{EU}\}]}\end{array}$ \\
\hline
\end{tabular}

Note: In the table we omit the trivial internally stable coalition structure where all players stand-alone (the singleton). 
Table 10: Sensitivity analysis for the parameters in the cost functions when the players stand-alone.

\begin{tabular}{|c|c|c|c|c|}
\hline Grand coalition & Benchmark case & Case 31: $\{$ EU $\}$ decrease & Case 32: $\{E U\}$ increase & Case 33: $\{\mathrm{NO}\}$ decrease \\
\hline$[\{\mathrm{EU}, \mathrm{NO}, \mathrm{IC}, \mathrm{FI}\}]$ & $\{784\}$ & $\{784\}$ & $\{784\}$ & $\{784\}$ \\
\hline \multicolumn{5}{|c|}{$\begin{array}{l}\text { Three-player against one- } \\
\text { player }\end{array}$} \\
\hline$[\{\mathrm{EU}, \mathrm{NO}, \mathrm{IC}\} ;\{\mathrm{FI}\}]$ & $\{548\},\{259\}$ & $\{548\},\{259\}$ & $\{548\},\{259\}$ & $\{548\},\{259\}$ \\
\hline$[\{\mathrm{EU}, \mathrm{NO}, \mathrm{FI}\} ;\{\mathrm{IC})]$ & $\{491\},\{275\}$ & $\{491\},\{275\}$ & $\{491\},\{275\}$ & $\{491\},\{275\}$ \\
\hline$[\{\mathrm{EU}, \mathrm{IC}, \mathrm{FI}\} ;\{\mathrm{NO}\}]$ & $\{653\},\{100\}$ & $\{653\},\{100\}$ & $\{653\},\{100\}$ & $\{653\},\{100\}$ \\
\hline$[\{\mathrm{NO}, \mathrm{IC}, \mathrm{FI}\} ;\{\mathrm{EU}\}]$ & $\{622\},\{242\}$ & $\{622\},\{242\}$ & $\{622\},\{242\}$ & $\{622\},\{242\}$ \\
\hline \multicolumn{5}{|c|}{$\begin{array}{l}\text { Two-player against two- } \\
\text { player }\end{array}$} \\
\hline$[\{\mathrm{EU}, \mathrm{NO}\} ;\{\mathrm{IC}, \mathrm{FI}\}]$ & $\{298\},\{590\}$ & $\{298\},\{590\}$ & $\{298\},\{590\}$ & $\{298\},\{590\}$ \\
\hline$[\{\mathrm{EU}, \mathrm{IC}\} ;\{\mathrm{NO}, \mathrm{FI}\}]$ & $\{504\},\{316\}$ & $\{504\},\{316\}$ & $\{504\},\{316\}$ & $\{504\},\{316\}$ \\
\hline$[\{\mathrm{EU}, \mathrm{FI}\} ;\{\mathrm{NO}, \mathrm{IC}\}]$ & $\{359\},\{339\}$ & $\{359\},\{339\}$ & $\{359\},\{339\}$ & $\{359\},\{339\}$ \\
\hline \multicolumn{5}{|c|}{$\begin{array}{l}\text { Two-player against one- } \\
\text { player }\end{array}$} \\
\hline$[\{\mathrm{EU}, \mathrm{NO}\} ;\{\mathrm{IC}\} ;\{\mathrm{FI}\}]$ & $\{303\},\{266\},\{254\}$ & $\{303\},\{266\},\{254\}$ & $\{303\},\{266\},\{254\}$ & $\{303\},\{266\},\{254\}$ \\
\hline$[\{\mathrm{EU}, \mathrm{IC}\} ;\{\mathrm{NO}\} ;\{\mathrm{FI}\}]$ & $\{496\},\{96\},\{253\}$ & $\{496\},\{96\},\{253\}$ & $\{496\},\{96\},\{253\}$ & $\{496\},\{96\},\{253\}$ \\
\hline$[\{\mathrm{EU}, \mathrm{FI}\} ;\{\mathrm{NO}\} ;\{\mathrm{IC}\}]$ & $\{353\},\{100\},\{277\}$ & $\{353\},\{100\},\{277\}$ & $\{353\},\{100\},\{277\}$ & $\{353\},\{100\},\{277\}$ \\
\hline$[\{\mathrm{NO}, \mathrm{IC}\} ;\{\mathrm{EU}\} ;\{\mathrm{FI}\}]$ & $\{320\},\{243\},\{255\}$ & $\{320\},\{243\},\{255\}$ & $\{320\},\{243\},\{255\}$ & $\{320\},\{243\},\{255\}$ \\
\hline$[\{\mathrm{NO}, \mathrm{FI}\} ;\{\mathrm{EU}\} ;\{\mathrm{IC}\}]$ & $\{313\},\{243\},\{266\}$ & $\{313\},\{243\},\{266\}$ & $\{313\},\{243\},\{266\}$ & $\{313\},\{243\},\{266\}$ \\
\hline$[\{\mathrm{IC}, \mathrm{FI}\} ;\{\mathrm{EU}\} ;(\mathrm{NO}\}]$ & $\{582\},\{236\},\{93\}$ & $\{582\},\{236\},\{93\}$ & $\{582\},\{236\},\{93\}$ & $\{582\},\{236\},\{93\}$ \\
\hline \multicolumn{5}{|l|}{ Standing-alone } \\
\hline$[\{\mathrm{EU}\} ;\{\mathrm{NO}\} ;\{\mathrm{IC}\} ;\{\mathrm{FI}\}]$ & $\{239\},\{95\},\{263\},\{250\}$ & $\{277\},\{93\},\{259\},\{247\}$ & $\{211\},\{96\},\{265\},\{253\}$ & $\{239\},\{104\},\{262\},\{250\}$ \\
\hline \multicolumn{5}{|c|}{ Internally stable coalitions } \\
\hline Coalition structures & {$[\{\mathrm{IC}, \mathrm{FI}\} ;\{\mathrm{EU}\} ;(\mathrm{NO}\}]$} & {$[\{\mathrm{IC}, \mathrm{FI}\} ;\{\mathrm{EU}\} ;(\mathrm{NO}\}]$} & $\begin{array}{l}{[\{\mathrm{IC}, \mathrm{FI}\} ;\{\mathrm{EU}\} ;(\mathrm{NO}\}],} \\
{[\{\mathrm{EU}, \mathrm{IC}\} ;\{\mathrm{NO}\} ;\{\mathrm{FI}\}]}\end{array}$ & {$[\{\mathrm{IC}, \mathrm{FI}\} ;\{\mathrm{EU}\} ;(\mathrm{NO}\}]$} \\
\hline
\end{tabular}


Table 10 (continued).

\begin{tabular}{|c|c|c|c|c|}
\hline Grand coalition & Benchmark case & Case 34: $\{\mathrm{NO}\}$ increase & Case 35: $\{I C\}$ decrease & Case 36: $\{I C\}$ increase \\
\hline$[\{\mathrm{EU}, \mathrm{NO}, \mathrm{IC}, \mathrm{FI}\}]$ & $\{784\}$ & $\{784\}$ & $\{784\}$ & $\{784\}$ \\
\hline \multicolumn{5}{|c|}{$\begin{array}{l}\text { Three-player against one- } \\
\text { player }\end{array}$} \\
\hline$[\{\mathrm{EU}, \mathrm{NO}, \mathrm{IC}\} ;\{\mathrm{FI}\}]$ & $\{548\},\{259\}$ & $\{548\},\{259\}$ & $\{548\},\{259\}$ & $\{548\},\{259\}$ \\
\hline$[\{\mathrm{EU}, \mathrm{NO}, \mathrm{FI}\} ;\{\mathrm{IC})]$ & $\{491\},\{275\}$ & $\{491\},\{275\}$ & $\{491\},\{275\}$ & $\{491\},\{275\}$ \\
\hline$[\{\mathrm{EU}, \mathrm{IC}, \mathrm{FI}\} ;\{\mathrm{NO}\}]$ & $\{653\},\{100\}$ & $\{653\},\{100\}$ & $\{653\},\{100\}$ & $\{653\},\{100\}$ \\
\hline$[\{\mathrm{NO}, \mathrm{IC}, \mathrm{FI}\} ;\{\mathrm{EU}\}]$ & $\{622\},\{242\}$ & $\{622\},\{242\}$ & $\{622\},\{242\}$ & $\{622\},\{242\}$ \\
\hline \multicolumn{5}{|c|}{$\begin{array}{l}\text { Two-player against two- } \\
\text { player }\end{array}$} \\
\hline$[\{\mathrm{EU}, \mathrm{NO}\} ;\{\mathrm{IC}, \mathrm{FI}\}]$ & $\{298\},\{590\}$ & $\{298\},\{590\}$ & $\{298\},\{590\}$ & $\{298\},\{590\}$ \\
\hline$[\{\mathrm{EU}, \mathrm{IC}\} ;\{\mathrm{NO}, \mathrm{FI}\}]$ & $\{504\},\{316\}$ & $\{504\},\{316\}$ & $\{504\},\{316\}$ & $\{504\},\{316\}$ \\
\hline$[\{\mathrm{EU}, \mathrm{FI}\} ;\{\mathrm{NO}, \mathrm{IC}\}]$ & $\{359\},\{339\}$ & $\{359\},\{339\}$ & $\{359\},\{339\}$ & $\{359\},\{339\}$ \\
\hline \multicolumn{5}{|c|}{$\begin{array}{l}\text { Two-player against one- } \\
\text { player }\end{array}$} \\
\hline$[\{\mathrm{EU}, \mathrm{NO}\} ;\{\mathrm{IC}\} ;\{\mathrm{FI}\}]$ & $\{303\},\{266\},\{254\}$ & $\{303\},\{266\},\{254\}$ & $\{303\},\{266\},\{254\}$ & $\{303\},\{266\},\{254\}$ \\
\hline$[\{\mathrm{EU}, \mathrm{IC}\} ;\{\mathrm{NO}\} ;\{\mathrm{FI}\}]$ & $\{496\},\{96\},\{253\}$ & $\{496\},\{96\},\{253\}$ & $\{496\},\{96\},\{253\}$ & $\{496\},\{96\},\{253\}$ \\
\hline$[\{\mathrm{EU}, \mathrm{FI}\} ;\{\mathrm{NO}\} ;\{\mathrm{IC}\}]$ & $\{353\},\{100\},\{277\}$ & $\{353\},\{100\},\{277\}$ & $\{353\},\{100\},\{277\}$ & $\{353\},\{100\},\{277\}$ \\
\hline$[\{\mathrm{NO}, \mathrm{IC}\} ;\{\mathrm{EU}\} ;\{\mathrm{FI}\}]$ & $\{320\},\{243\},\{255\}$ & $\{320\},\{243\},\{255\}$ & $\{320\},\{243\},\{255\}$ & $\{320\},\{243\},\{255\}$ \\
\hline$[\{\mathrm{NO}, \mathrm{FI}\} ;\{\mathrm{EU}\} ;\{\mathrm{IC}\}]$ & $\{313\},\{243\},\{266\}$ & $\{313\},\{243\},\{266\}$ & $\{313\},\{243\},\{266\}$ & $\{313\},\{243\},\{266\}$ \\
\hline$[\{\mathrm{IC}, \mathrm{FI}\} ;\{\mathrm{EU}\} ;(\mathrm{NO}\}]$ & $\{582\},\{236\},\{93\}$ & $\{582\},\{236\},\{93\}$ & $\{582\},\{236\},\{93\}$ & $\{582\},\{236\},\{93\}$ \\
\hline \multicolumn{5}{|l|}{ Standing-alone } \\
\hline$[\{\mathrm{EU}\} ;\{\mathrm{NO}\} ;\{\mathrm{IC}\} ;\{\mathrm{FI}\}]$ & $\{239\},\{95\},\{263\},\{250\}$ & $\{240\},\{87\},\{263\},\{251\}$ & $\{237\},\{93\},\{298\},\{247\}$ & $\{242\},\{96\},\{235\},\{253\}$ \\
\hline \multicolumn{5}{|c|}{ Internally stable coalitions } \\
\hline Coalition structures & {$[\{\mathrm{IC}, \mathrm{FI}\} ;\{\mathrm{EU}\} ;(\mathrm{NO}\}]$} & {$[\{\mathrm{IC}, \mathrm{FI}\} ;\{\mathrm{EU}\} ;(\mathrm{NO}\}]$} & {$[\{\mathrm{IC}, \mathrm{FI}\} ;\{\mathrm{EU}\} ;(\mathrm{NO}\}]$} & $\begin{array}{l}{[\{\mathrm{IC}, \mathrm{FI}\} ;\{\mathrm{EU}\} ;(\mathrm{NO}\}]} \\
{[\{\mathrm{EU}, \mathrm{IC}\} ;\{\mathrm{NO}\} ;\{\mathrm{FI}\}]}\end{array}$ \\
\hline
\end{tabular}


Table 10 (continued).

\begin{tabular}{|c|c|c|c|}
\hline Grand coalition & Benchmark case & Case 37: $\{\mathrm{FI}\}$ decrease & Case 38: $\{F I\}$ increase \\
\hline$[\{\mathrm{EU}, \mathrm{NO}, \mathrm{IC}, \mathrm{FI}\}]$ & $\{784\}$ & $\{784\}$ & $\{784\}$ \\
\hline \multicolumn{4}{|c|}{$\begin{array}{l}\text { Three-player against one- } \\
\text { player }\end{array}$} \\
\hline$[\{\mathrm{EU}, \mathrm{NO}, \mathrm{IC}\} ;\{\mathrm{FI}\}]$ & $\{548\},\{259\}$ & $\{548\},\{259\}$ & $\{548\},\{259\}$ \\
\hline$[\{\mathrm{EU}, \mathrm{NO}, \mathrm{FI}\} ;\{\mathrm{IC})]$ & $\{491\},\{275\}$ & $\{491\},\{275\}$ & $\{491\},\{275\}$ \\
\hline$[\{\mathrm{EU}, \mathrm{IC}, \mathrm{FI}\} ;\{\mathrm{NO}\}]$ & $\{653\},\{100\}$ & $\{653\},\{100\}$ & $\{653\},\{100\}$ \\
\hline$[\{\mathrm{NO}, \mathrm{IC}, \mathrm{FI}\} ;\{\mathrm{EU}\}]$ & $\{622\},\{242\}$ & $\{622\},\{242\}$ & $\{622\},\{242\}$ \\
\hline \multicolumn{4}{|c|}{$\begin{array}{l}\text { Two-player against two- } \\
\text { player }\end{array}$} \\
\hline$[\{\mathrm{EU}, \mathrm{NO}\} ;\{\mathrm{IC}, \mathrm{FI}\}]$ & $\{298\},\{590\}$ & $\{298\},\{590\}$ & $\{298\},\{590\}$ \\
\hline$[\{\mathrm{EU}, \mathrm{IC}\} ;\{\mathrm{NO}, \mathrm{FI}\}]$ & $\{504\},\{316\}$ & $\{504\},\{316\}$ & $\{504\},\{316\}$ \\
\hline$[\{\mathrm{EU}, \mathrm{FI}\} ;\{\mathrm{NO}, \mathrm{IC}\}]$ & $\{359\},\{339\}$ & $\{359\},\{339\}$ & $\{359\},\{339\}$ \\
\hline \multicolumn{4}{|c|}{$\begin{array}{l}\text { Two-player against one- } \\
\text { player }\end{array}$} \\
\hline$[\{\mathrm{EU}, \mathrm{NO}\} ;\{\mathrm{IC}\} ;\{\mathrm{FI}\}]$ & $\{303\},\{266\},\{254\}$ & $\{303\},\{266\},\{254\}$ & $\{303\},\{266\},\{254\}$ \\
\hline$[\{\mathrm{EU}, \mathrm{IC}\} ;\{\mathrm{NO}\} ;\{\mathrm{FI}\}]$ & $\{496\},\{96\},\{253\}$ & $\{496\},\{96\},\{253\}$ & $\{496\},\{96\},\{253\}$ \\
\hline$[\{\mathrm{EU}, \mathrm{FI}\} ;\{\mathrm{NO}\} ;\{\mathrm{IC}\}]$ & $\{353\},\{100\},\{277\}$ & $\{353\},\{100\},\{277\}$ & $\{353\},\{100\},\{277\}$ \\
\hline$[\{\mathrm{NO}, \mathrm{IC}\} ;\{\mathrm{EU}\} ;\{\mathrm{FI}\}]$ & $\{320\},\{243\},\{255\}$ & $\{320\},\{243\},\{255\}$ & $\{320\},\{243\},\{255\}$ \\
\hline$[\{\mathrm{NO}, \mathrm{FI}\} ;\{\mathrm{EU}\} ;\{\mathrm{IC}\}]$ & $\{313\},\{243\},\{266\}$ & $\{313\},\{243\},\{266\}$ & $\{313\},\{243\},\{266\}$ \\
\hline$[\{\mathrm{IC}, \mathrm{FI}\} ;\{\mathrm{EU}\} ;(\mathrm{NO}\}]$ & $\{582\},\{236\},\{93\}$ & $\{582\},\{236\},\{93\}$ & $\{582\},\{236\},\{93\}$ \\
\hline \multicolumn{4}{|l|}{ Standing-alone } \\
\hline$[\{\mathrm{EU}\} ;\{\mathrm{NO}\} ;\{\mathrm{IC}\} ;\{\mathrm{FI}\}]$ & $\{239\},\{95\},\{263\},\{250\}$ & $\{236\},\{93\},\{259\},\{290\}$ & $\{242\},\{96\},\{265\},\{221\}$ \\
\hline \multicolumn{4}{|c|}{ Internally stable coalitions } \\
\hline Coalition structures & {$[\{\mathrm{IC}, \mathrm{FI}\} ;\{\mathrm{EU}\} ;(\mathrm{NO}\}]$} & {$[\{\mathrm{IC}, \mathrm{FI}\} ;\{\mathrm{EU}\} ;(\mathrm{NO}\}]$} & {$[\{\mathrm{IC}, \mathrm{FI}\} ;\{\mathrm{EU}\} ;(\mathrm{NO}\}]$} \\
\hline
\end{tabular}

Note: In the table we omit the trivial internally stable coalition structure where all players stand-alone (the singleton). 
Table 11: Sensitivity analysis for the parameters in all coalition cost functions involving a player.

\begin{tabular}{|c|c|c|c|c|}
\hline Grand coalition & Benchmark case & Case 39: $\{\mathrm{EU}\}$ decrease & Case 40: $\{E U\}$ increase & Case 41: $\{$ NO $\}$ decrease \\
\hline$[\{\mathrm{EU}, \mathrm{NO}, \mathrm{IC}, \mathrm{FI}\}]$ & $\{784\}$ & $\{860\}$ & $\{718\}$ & $\{860\}$ \\
\hline \multicolumn{5}{|c|}{$\begin{array}{l}\text { Three-player against one- } \\
\text { player }\end{array}$} \\
\hline$[\{\mathrm{EU}, \mathrm{NO}, \mathrm{IC}\} ;\{\mathrm{FI}\}]$ & $\{548\},\{259\}$ & $\{637\},\{251\}$ & $\{481\},\{265\}$ & $\{637\},\{251\}$ \\
\hline$[\{\mathrm{EU}, \mathrm{NO}, \mathrm{FI}\} ;\{\mathrm{IC})]$ & $\{491\},\{275\}$ & $\{585\},\{266\}$ & $\{422\},\{282\}$ & $\{585\},\{266\}$ \\
\hline$[\{\mathrm{EU}, \mathrm{IC}, \mathrm{FI}\} ;\{\mathrm{NO}\}]$ & $\{653\},\{100\}$ & $\{761\},\{97\}$ & $\{572\},\{103\}$ & $\{651\},\{110\}$ \\
\hline$[\{\mathrm{NO}, \mathrm{IC}, \mathrm{FI}\} ;\{\mathrm{EU}\}]$ & $\{622\},\{242\}$ & $\{614\},\{280\}$ & $\{628\},\{213\}$ & $\{738\},\{232\}$ \\
\hline \multicolumn{5}{|c|}{$\begin{array}{l}\text { Two-player against two- } \\
\text { player }\end{array}$} \\
\hline$[\{\mathrm{EU}, \mathrm{NO}\} ;\{\mathrm{IC}, \mathrm{FI}\}]$ & $\{298\},\{590\}$ & $\{339\},\{651\}$ & $\{266\},\{539\}$ & $\{347\},\{580\}$ \\
\hline$[\{\mathrm{EU}, \mathrm{IC}\} ;\{\mathrm{NO}, \mathrm{FI}\}]$ & $\{504\},\{316\}$ & $\{556\},\{310\}$ & $\{460\},\{321\}$ & $\{495\},\{367\}$ \\
\hline$[\{\mathrm{EU}, \mathrm{FI}\} ;\{\mathrm{NO}, \mathrm{IC}\}]$ & $\{359\},\{339\}$ & $\{398\},\{334\}$ & $\{327\},\{342\}$ & $\{353\},\{390\}$ \\
\hline \multicolumn{5}{|c|}{$\begin{array}{l}\text { Two-player against one- } \\
\text { player }\end{array}$} \\
\hline$[\{\mathrm{EU}, \mathrm{NO}\} ;\{\mathrm{IC}\} ;\{\mathrm{FI}\}]$ & $\{303\},\{266\},\{254\}$ & $\{353\},\{262\},\{250\}$ & $\{265\},\{270\},\{257\}$ & $\{353\},\{262\},\{250\}$ \\
\hline$[\{\mathrm{EU}, \mathrm{IC}\} ;\{\mathrm{NO}\} ;\{\mathrm{FI}\}]$ & $\{496\},\{96\},\{253\}$ & $\{548\},\{94\},\{249\}$ & $\{454\},\{97\},\{257\}$ & $\{495\},\{105\},\{252\}$ \\
\hline$[\{\mathrm{EU}, \mathrm{FI}\} ;\{\mathrm{NO}\} ;\{\mathrm{IC}\}]$ & $\{353\},\{100\},\{277\}$ & $\{392\},\{99\},\{274\}$ & $\{322\},\{101\},\{280\}$ & $\{352\},\{109\},\{277\}$ \\
\hline$[\{\mathrm{NO}, \mathrm{IC}\} ;\{\mathrm{EU}\} ;\{\mathrm{FI}\}]$ & $\{320\},\{243\},\{255\}$ & $\{316\},\{282\},\{251\}$ & $\{324\},\{214\},\{257\}$ & $\{369\},\{239\},\{250\}$ \\
\hline$[\{\mathrm{NO}, \mathrm{FI}\} ;\{\mathrm{EU}\} ;\{\mathrm{IC}\}]$ & $\{313\},\{243\},\{266\}$ & $\{309\},\{281\},\{263\}$ & $\{316\},\{214\},\{269\}$ & $\{363\},\{239\},\{262\}$ \\
\hline$[\{\mathrm{IC}, \mathrm{FI}\} ;\{\mathrm{EU}\} ;(\mathrm{NO}\}]$ & $\{582\},\{236\},\{93\}$ & $\{574\},\{273\},\{92\}$ & $\{587\},\{208\},\{94\}$ & $\{580\},\{235\},\{102\}$ \\
\hline \multicolumn{5}{|l|}{ Standing-alone } \\
\hline$[\{\mathrm{EU}\} ;\{\mathrm{NO}\} ;\{\mathrm{IC}\} ;\{\mathrm{FI}\}]$ & $\{239\},\{95\},\{263\},\{250\}$ & $\{277\},\{93\},\{259\},\{247\}$ & $\{211\},\{96\},\{265\},\{253\}$ & $\{239\},\{104\},\{262\},\{250\}$ \\
\hline \multicolumn{5}{|c|}{ Internally stable coalitions } \\
\hline Coalition structures & {$[\{\mathrm{IC}, \mathrm{FI}\} ;\{\mathrm{EU}\} ;(\mathrm{NO}\}]$} & $\begin{array}{l}{[\{\mathrm{IC}, \mathrm{FI}\} ;\{\mathrm{EU}\} ;(\mathrm{NO}\}],} \\
{[\{\mathrm{EU}, \mathrm{IC}\} ;\{\mathrm{NO}\} ;\{\mathrm{FI}\}]}\end{array}$ & {$[\{\mathrm{IC}, \mathrm{FI}\} ;\{\mathrm{EU}\} ;(\mathrm{NO}\}]$} & $\begin{array}{l}\{\mathrm{IC}, \mathrm{FI}\} ;\{\mathrm{EU}\} ; \mathrm{NO}\}], \\
{[\{\mathrm{EU}, \mathrm{NO}, \mathrm{IC}\} ;\{\mathrm{FI}\}]} \\
{[\{\mathrm{EU}, \mathrm{NO}, \mathrm{FI}\} ; \mathrm{IIC}\},} \\
{[\{\mathrm{NO}, \mathrm{IC}, \mathrm{FI}\} ;\{\mathrm{EU}\}],} \\
{[\{\mathrm{EU}, \mathrm{NO}\} ;\{\mathrm{IC}, \mathrm{FI}\}],} \\
[\{\mathrm{EU}, \mathrm{NO}\} ;\{\mathrm{IC}\}, \mathrm{FI}\}], \\
{[\{\mathrm{NO}, \mathrm{IC}\} ;\{\mathrm{EU}\}\{\mathrm{FI}\}],} \\
{[\{\mathrm{NO}, \mathrm{FI}\} ;\{\mathrm{NO}\},\{\mathrm{FI}\}]}\end{array}$ \\
\hline
\end{tabular}


Table 11 (continued).

\begin{tabular}{|c|c|c|c|c|}
\hline Grand coalition & Benchmark case & Case 42: $\{\mathrm{NO}\}$ increase & Case43: $\{$ IC $\}$ decrease & Case 44: $\{$ IC $\}$ increase \\
\hline$[\{\mathrm{EU}, \mathrm{NO}, \mathrm{IC}, \mathrm{FI}\}]$ & $\{784\}$ & $\{718\}$ & $\{860\}$ & $\{718\}$ \\
\hline \multicolumn{5}{|c|}{$\begin{array}{l}\text { Three-player against one- } \\
\text { player }\end{array}$} \\
\hline$[\{\mathrm{EU}, \mathrm{NO}, \mathrm{IC}\} ;\{\mathrm{FI}\}]$ & $\{548\},\{259\}$ & $\{481\},\{265\}$ & $\{637\},\{251\}$ & $\{481\},\{265\}$ \\
\hline$[\{\mathrm{EU}, \mathrm{NO}, \mathrm{FI}\} ;\{\mathrm{IC})]$ & $\{491\},\{275\}$ & $\{422\},\{282\}$ & $\{485\},\{312\}$ & $\{496\},\{246\}$ \\
\hline$[\{\mathrm{EU}, \mathrm{IC}, \mathrm{FI}\} ;\{\mathrm{NO}\}]$ & $\{653\},\{100\}$ & $\{655\},\{92\}$ & $\{761\},\{97\}$ & $\{572\},\{103\}$ \\
\hline$[\{\mathrm{NO}, \mathrm{IC}, \mathrm{FI}\} ;\{\mathrm{EU}\}]$ & $\{622\},\{242\}$ & $\{537\},\{249\}$ & $\{738\},\{232\}$ & $\{537\},\{249\}$ \\
\hline \multicolumn{5}{|c|}{$\begin{array}{l}\text { Two-player against two- } \\
\text { player }\end{array}$} \\
\hline$[\{\mathrm{EU}, \mathrm{NO}\} ;\{\mathrm{IC}, \mathrm{FI}\}]$ & $\{298\},\{590\}$ & $\{261\},\{597\}$ & $\{291\},\{662\}$ & $\{304\},\{532\}$ \\
\hline$[\{\mathrm{EU}, \mathrm{IC}\} ;\{\mathrm{NO}, \mathrm{FI}\}]$ & $\{504\},\{316\}$ & $\{507\},\{296\}$ & $\{556\},\{310\}$ & $\{460\},\{321\}$ \\
\hline$[\{\mathrm{EU}, \mathrm{FI}\} ;\{\mathrm{NO}, \mathrm{IC}\}]$ & $\{359\},\{339\}$ & $\{364\},\{299\}$ & $\{353\},\{390\}$ & $\{364\},\{299\}$ \\
\hline \multicolumn{5}{|c|}{$\begin{array}{l}\text { Two-player against one- } \\
\text { player }\end{array}$} \\
\hline$[\{\mathrm{EU}, \mathrm{NO}\} ;\{\mathrm{IC}\} ;\{\mathrm{FI}\}]$ & $\{303\},\{266\},\{254\}$ & $\{265\},\{270\},\{257\}$ & $\{299\},\{302\},\{251\}$ & $\{306\},\{238\},\{257\}$ \\
\hline$[\{\mathrm{EU}, \mathrm{IC}\} ;\{\mathrm{NO}\} ;\{\mathrm{FI}\}]$ & $\{496\},\{96\},\{253\}$ & $\{498\},\{88\},\{254\}$ & $\{548\},\{94\},\{249\}$ & $\{454\},\{97\},\{257\}$ \\
\hline$[\{\mathrm{EU}, \mathrm{FI}\} ;\{\mathrm{NO}\} ;\{\mathrm{IC}\}]$ & $\{353\},\{100\},\{277\}$ & $\{354\},\{92\},\{278\}$ & $\{349\},\{99\},\{315\}$ & $\{357\},\{101\},\{248\}$ \\
\hline$[\{\mathrm{NO}, \mathrm{IC}\} ;\{\mathrm{EU}\} ;\{\mathrm{FI}\}]$ & $\{320\},\{243\},\{255\}$ & $\{283\},\{247\},\{258\}$ & $\{369\},\{239\},\{250\}$ & $\{283\},\{247\},\{258\}$ \\
\hline$[\{\mathrm{NO}, \mathrm{FI}\} ;\{\mathrm{EU}\} ;\{\mathrm{IC}\}]$ & $\{313\},\{243\},\{266\}$ & $\{293\},\{245\},\{268\}$ & $\{309\},\{240\},\{302\}$ & $\{316\},\{245\},\{238\}$ \\
\hline$[\{\mathrm{IC}, \mathrm{FI}\} ;\{\mathrm{EU}\} ;(\mathrm{NO}\}]$ & $\{582\},\{236\},\{93\}$ & $\{583\},\{236\},\{86\}$ & $\{658\},\{229\},\{91\}$ & $\{521\},\{241\},\{95\}$ \\
\hline \multicolumn{5}{|l|}{ Standing-alone } \\
\hline$[\{\mathrm{EU}\} ;\{\mathrm{NO}\} ;\{\mathrm{IC}\} ;\{\mathrm{FI}\}]$ & $\{239\},\{95\},\{263\},\{250\}$ & $\{240\},\{87\},\{263\},\{251\}$ & $\{237\},\{93\},\{298\},\{247\}$ & $\{242\},\{96\},\{235\},\{253\}$ \\
\hline \multicolumn{5}{|c|}{ Internally stable coalitions } \\
\hline Coalition structures & {$[\{I C, F I\} ;\{E U\} ;(N O\}]$} & {$[\{\mathrm{IC}, \mathrm{FI}\} ;\{\mathrm{EU}\} ;(\mathrm{NO}\}]$} & $\begin{array}{l}[\{\mathrm{IC}, \mathrm{FI}\} ;\{\mathrm{EU}\} ; \mathrm{NO}\}] \\
{[\{\mathrm{EU}, \mathrm{IC}\} ;\{\mathrm{NO}\} ;\{\mathrm{FI}\}]}\end{array}$ & {$[\{I C, F I\} ;\{E U\} ;(N O\}]$} \\
\hline
\end{tabular}


Table 11 (continued).

\begin{tabular}{|c|c|c|c|}
\hline Grand coalition & Benchmark case & Case 45: $\{\mathrm{FI}\}$ decrease & Case 46: $\{F I\}$ increase \\
\hline$[\{\mathrm{EU}, \mathrm{NO}, \mathrm{IC}, \mathrm{FI}\}]$ & $\{784\}$ & $\{860\}$ & $\{718\}$ \\
\hline \multicolumn{4}{|c|}{$\begin{array}{l}\text { Three-player against one- } \\
\text { player }\end{array}$} \\
\hline$[\{\mathrm{EU}, \mathrm{NO}, \mathrm{IC}\} ;\{\mathrm{FI}\}]$ & $\{548\},\{259\}$ & $\{540\},\{299\}$ & $\{554\},\{228\}$ \\
\hline$[\{\mathrm{EU}, \mathrm{NO}, \mathrm{FI}\} ;\{\mathrm{IC})]$ & $\{491\},\{275\}$ & $\{585\},\{266\}$ & $\{422\},\{282\}$ \\
\hline$[\{\mathrm{EU}, \mathrm{IC}, \mathrm{FI}\} ;\{\mathrm{NO}\}]$ & $\{653\},\{100\}$ & $\{761\},\{97\}$ & $\{572\},\{103\}$ \\
\hline$[\{\mathrm{NO}, \mathrm{IC}, \mathrm{FI}\} ;\{\mathrm{EU}\}]$ & $\{622\},\{242\}$ & $\{738\},\{232\}$ & $\{537\},\{249\}$ \\
\hline \multicolumn{4}{|c|}{$\begin{array}{l}\text { Two-player against two- } \\
\text { player }\end{array}$} \\
\hline$[\{\mathrm{EU}, \mathrm{NO}\} ;\{\mathrm{IC}, \mathrm{FI}\}]$ & $\{298\},\{590\}$ & $\{298\},\{590\}$ & $\{298\},\{590\}$ \\
\hline$[\{\mathrm{EU}, \mathrm{IC}\} ;\{\mathrm{NO}, \mathrm{FI}\}]$ & $\{504\},\{316\}$ & $\{495\},\{367\}$ & $\{510\},\{278\}$ \\
\hline$[\{\mathrm{EU}, \mathrm{FI}\} ;\{\mathrm{NO}, \mathrm{IC}\}]$ & $\{359\},\{339\}$ & $\{398\},\{334\}$ & $\{327\},\{342\}$ \\
\hline \multicolumn{4}{|c|}{$\begin{array}{l}\text { Two-player against one- } \\
\text { player }\end{array}$} \\
\hline$[\{\mathrm{EU}, \mathrm{NO}\} ;\{\mathrm{IC}\} ;\{\mathrm{FI}\}]$ & $\{303\},\{266\},\{254\}$ & $\{299\},\{263\},\{294\}$ & $\{306\},\{269\},\{224\}$ \\
\hline$[\{\mathrm{EU}, \mathrm{IC}\} ;\{\mathrm{NO}\} ;\{\mathrm{FI}\}]$ & $\{496\},\{96\},\{253\}$ & $\{490\},\{94\},\{292\}$ & $\{502\},\{97\},\{223\}$ \\
\hline$[\{\mathrm{EU}, \mathrm{FI}\} ;\{\mathrm{NO}\} ;\{\mathrm{IC}\}]$ & $\{353\},\{100\},\{277\}$ & $\{392\},\{99\},\{274\}$ & $\{322\},\{101\},\{280\}$ \\
\hline$[\{\mathrm{NO}, \mathrm{IC}\} ;\{\mathrm{EU}\} ;\{\mathrm{FI}\}]$ & $\{320\},\{243\},\{255\}$ & $\{316\},\{240\},\{294\}$ & $\{324\},\{246\},\{224\}$ \\
\hline$[\{\mathrm{NO}, \mathrm{FI}\} ;\{\mathrm{EU}\} ;\{\mathrm{IC}\}]$ & $\{313\},\{243\},\{266\}$ & $\{363\},\{239\},\{262\}$ & $\{275\},\{246\},\{270\}$ \\
\hline$[\{\mathrm{IC}, \mathrm{FI}\} ;\{\mathrm{EU}\} ;(\mathrm{NO}\}]$ & $\{582\},\{236\},\{93\}$ & $\{658\},\{229\},\{91\}$ & $\{521\},\{241\},\{95\}$ \\
\hline \multicolumn{4}{|l|}{ Standing-alone } \\
\hline$[\{\mathrm{EU}\} ;\{\mathrm{NO}\} ;\{\mathrm{IC}\} ;\{\mathrm{FI}\}]$ & $\{239\},\{95\},\{263\},\{250\}$ & $\{236\},\{93\},\{259\},\{290\}$ & $\{242\},\{96\},\{265\},\{221\}$ \\
\hline \multicolumn{4}{|c|}{ Internally stable coalitions } \\
\hline Coalition structures & {$[\{\mathrm{IC}, \mathrm{FI}\} ;\{\mathrm{EU}\} ;(\mathrm{NO}\}]$} & {$[\{\mathrm{IC}, \mathrm{FI}\} ;\{\mathrm{EU}\} ;(\mathrm{NO}\}]$} & {$[\{\mathrm{IC}, \mathrm{FI}\} ;\{\mathrm{EU}\} ;(\mathrm{NO}\}]$} \\
\hline
\end{tabular}

Note: In the table we omit the trivial internally stable coalition structure where all players stand-alone (the singleton). 